\title{
An Archaeological Survey of the South Salado Creek Greenway: Rigsby Avenue to Southside Lion's Park East, San Antonio, Bexar County, Texas
}

Leonard Kemp

Center for Archeological Research, University of Texas at San Antonio

Bruce K. Moses

Follow this and additional works at: https://scholarworks.sfasu.edu/ita

Part of the American Material Culture Commons, Archaeological Anthropology Commons, Environmental Studies Commons, Other American Studies Commons, Other Arts and Humanities Commons, Other History of Art, Architecture, and Archaeology Commons, and the United States History Commons

Tell us how this article helped you.

This Article is brought to you for free and open access by the Center for Regional Heritage Research at SFA ScholarWorks. It has been accepted for inclusion in Index of Texas Archaeology: Open Access Gray Literature from the Lone Star State by an authorized editor of SFA ScholarWorks. For more information, please contact cdsscholarworks@sfasu.edu. 
An Archaeological Survey of the South Salado Creek Greenway: Rigsby Avenue to Southside Lion's Park East, San Antonio, Bexar County, Texas

\section{Creative Commons License}

\section{(c) (1) \&}

This work is licensed under a Creative Commons Attribution-NonCommercial 4.0 International License 


\title{
An Archaeological Survey of the South Salado Creek Greenway, San Antonio, Bexar County, Texas: Rigsby Avenue to Southside Lion's Park East
}

\author{
by \\ Leonard Kemp and Bruce K. Moses
}

with a contribution by

Cynthia M. Muñoz

Texas Antiquities Committee Permit No. 4702

\section{Principal Investigator}

Steve A. Tomka

Prepared for:

Rehler, Vaughn \& Koone, Inc.

745 E. Mulberry, Suite 601

San Antonio, Texas 78212
Prepared by:

Center for Archaeological Research The University of Texas at San Antonio Archaeological Report, No. 381 



\begin{abstract}
:
In October and November of 2007, The Center for Archaeological Research (CAR) of The University of Texas at San Antonio conducted an intensive pedestrian archaeological survey of the South Salado Creek located in San Antonio, Bexar County, Texas. The work was conducted in advance of construction of a multi-use greenway trail between Rigsby Avenue to Southside Lion's Park East along the Salado Creek proposed by the Parks and Recreation Department of the City of San Antonio and to fulfill contract requirements with Rehler, Vaughn \& Koone, Inc. (RVK) of San Antonio. RVK, in turn, was hired by the City of San Antonio. The survey was conducted under the requirements of the City of San Antonio Unified Development Code Chapter 35, Section 106 of the National Historic Preservation Act (NHPA) of 1966, and the Texas Antiquities Code. The survey was performed under Texas Antiquities Permit No. 4702, with Dr. Steve Tomka, CAR Director, serving as Principal Investigator and Leonard Kemp serving as the Project Archaeologist.
\end{abstract}

This report summarizes the results of the archaeological investigation, and provides recommendations regarding the management of cultural resources located in the project area. Pedestrian reconnaissance, and shovel tests were used to search for cultural resources within the project right of way (ROW). One archaeological site, 41BX1756 was found and recorded within the project area. It is a site with both prehistoric and historic components. The historic component consists of the remains of a house and an agricultural processing structure. In addition, two shovel tests adjacent to the facility were positive for prehistoric artifacts including debitage and burned rock. Field, laboratory and archival investigations suggest that neither the prehistoric nor historic components have significant research value. CAR recommends that because this site falls within the alternative trail designation the primary trail be utilized to avoid any impact to the site. In summary, because no significant deposits were found within the depth of impact along the proposed alignment, CAR recommends that the development of the South Salado Creek Greenway project proceed as planned.

Artifacts collected and records generated during this project were prepared for curation according to Texas Historical Commission guidelines and are permanently curated at the Center for Archaeological Research at the University of Texas at San Antonio. 


\section{Table of Contents:}

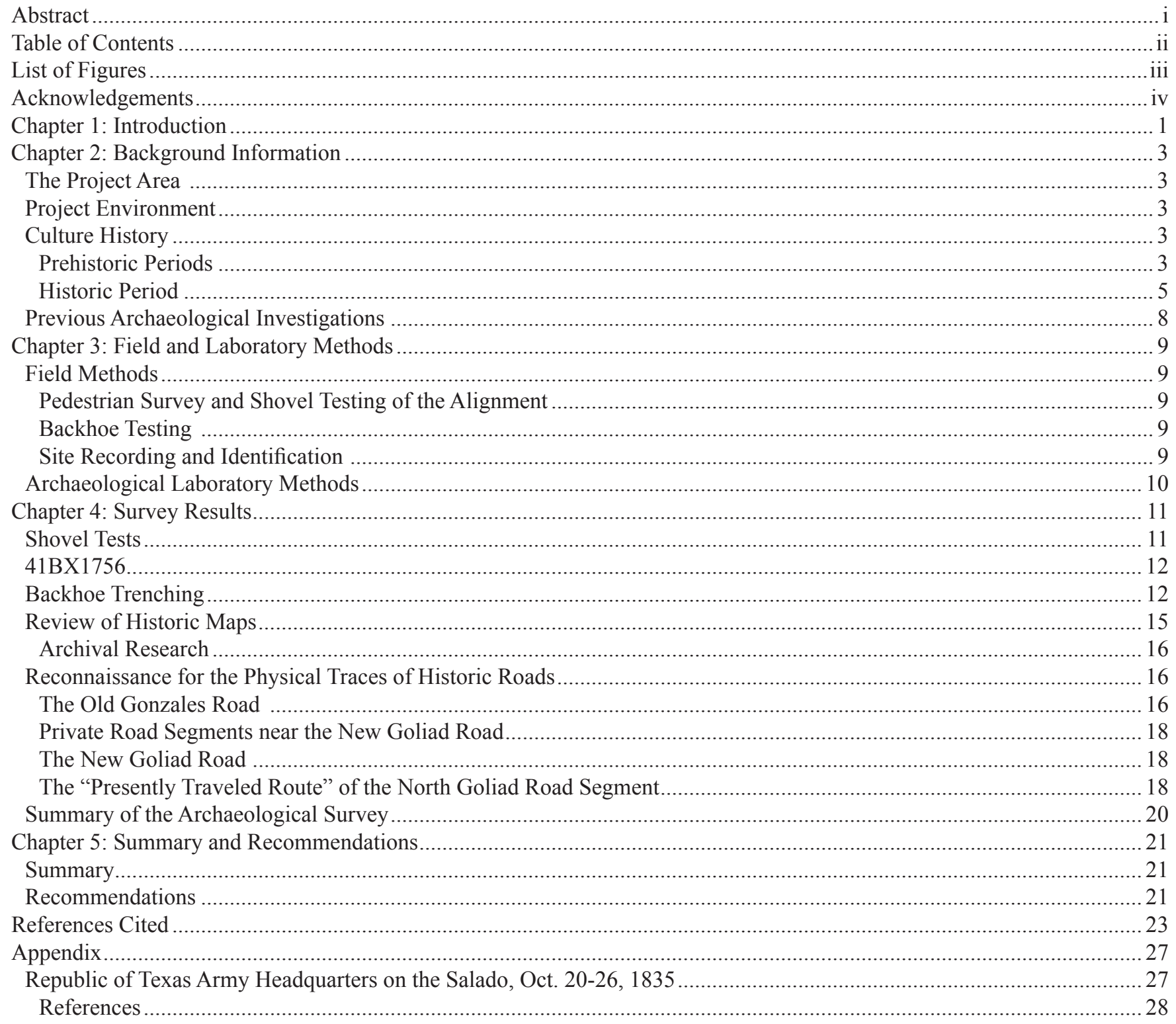




\section{List of Figures:}

Figure 1-1. The location of the project area on San Antonio East 7.5 Minute Series U.S.G.S. Quadrangle maps. ................... 1

Figure 2-1. The landscape and typical vegetation of the project area................................................................................. 4

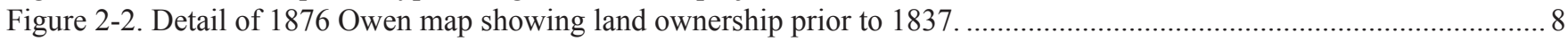

Figure 4-1. The project area depicted on 2005 photograph with shovel test locations........................................................ 11

Figure 4-2. The extent of 41BX1756 demarcated by solid black line. ......................................................................... 12

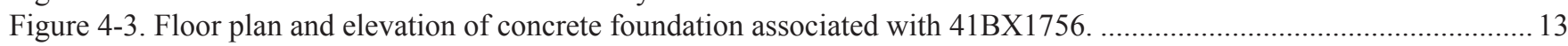

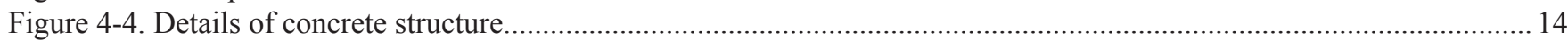

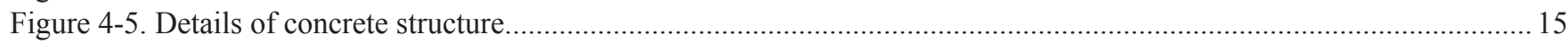

Figure 4-6. The 1953 San Antonio East 7.5 Minute Series U.S.G.S. Quadrangle map and 1937 Tobin aerial

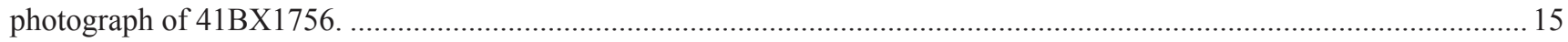

Figure 4-7. Close-up of the 1876 Owen map (left) showing details of roads and rioad traces within the project area. Modern aerial photograph (2005) on the right with locations checked for traces of historic roads. .......................... 17

Figure 4-8. Location of the Gonzales Road crossing of the Dry Salado immediately south of the fork in

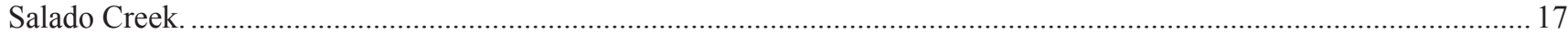

Figure 4-9. General area where the Gonzales Road crossed the main Salado Creek into modern Covington Park. ................ 18

Figure 4-10. Portion of road trace on private property detected using 2005 aerial image. ................................................ 19

Figure 4-11. Area where the "presently traveled road" depicted on Owen's map exits the Salado Creek

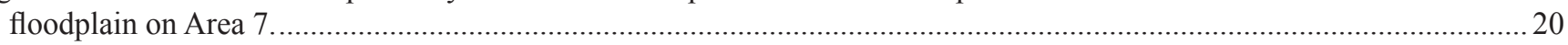

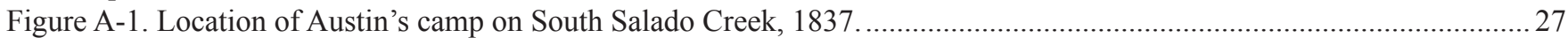




\section{Acknowledgements:}

The successful completion of this project is owed in a large part to the able and hard working field crew. They included Jon Dowling, and Jason Perez, both associated with the Center for Archaeological Research (CAR). Thank you for the walk in the park. The authors thank Cynthia Muñoz of CAR for contributing the field and lab methods chapter. All lab processing and curation was done under the supervision of Marybeth Tomka. CAR Director, Dr. Steve Tomka, served as Principal Investigator on the project and provided helpful comments on the report. The authors drafted the graphics used in this report and Bruce Moses edited the final manuscript. A special thanks also to Larry Hicks and Joseph Cannata, both of RVK, Inc. for their help during the project. 


\section{Chapter 1: Introduction}

The Center for Archaeological Research (CAR) of The University of Texas at San Antonio was contracted by Rehler, Vaughn \& Koone, Inc. (RVK, Inc.) of San Antonio to conduct an intensive pedestrian archaeological survey for the Salado Creek Greenway project located in San Antonio, Bexar County, Texas. The survey, conducted in advance of the proposed construction of a hike and bike trail, occurred in October and November of 2007. The principal goal of the pedestrian survey was to identify and document all prehistoric and/or historic archaeological sites that may be impacted by the proposed construction within the alignment of the hike and bike trail. The archaeological survey was performed under Texas Antiquities Permit No. 7402, with Dr. Steve Tomka, CAR Director, serving as Principal Investigator and Leonard Kemp serving as Project Archaeologist.

The land impacted by the project is owned by the City of San Antonio, a political subdivision of the State of Texas. As such, the project has to comply with State Historic Preservation laws and specifically the mandates of the Antiquities Code of Texas. The work was also coordinated through the City's Historic Preservation Office in compliance with the City of San Antonio Unified Development Code, Chapter 35. In addition, because the project area is located along a waterway, and a bridge will have to be constructed across Salado Creek, a 404 Nationwide Permit will have to be issued by the Corp of Engineers (COE). Projects receiving federal funding and/or permitting must comply with Section 106 of the National Historic Preservation Act (NHPA) of 1966. One outcome of the NHPA was the creation of the National Register of Historic Places (NRHP) and the Advisory Council of Historic Preservation. Section 106 of the NHPA stipulates that the Advisory Council must be given "a reasonable opportunity to comment" regarding the effect of any undertakings that could impact properties that may be eligible for inclusion in the National Register. All undertakings that derive from actions funded by, permitted by, or licensed by federal agencies fall under this requirement.
The project consists of development of a multi-use greenway trail running from Rigsby Ave. into Southside Lion's Park East along the Salado Creek channel crossing the Salado Creek and terminating at Southside Lion's Park West. The project area is within the Salado Creek watershed in south-east San Antonio. The Area of Potential Effect (APE) is approximately 2.3 miles (3701 meters) and runs through county parks, the Salado Creek watershed, and former agricultural lands. The right-of-way (ROW) is approximately 4 meters in width but varies in different locations of the project area. The proposed project is part of the City's long-range plan to maintain, improve, and expand existing multi-use greenway trails within San Antonio.

The Fieldwork consisted of a 100 percent pedestrian survey consisting of shovel testing of the approximately 2.3 mile long linear alignment. Figure 1-1 illustrates the project area on the San Antonio East, Texas USGS 7.5' quadrangles.

The survey of the South Salado Creek alignment included the excavation of 43 planned shovel tests. In the process of conducting the South Salado Creek Greenway survey, one

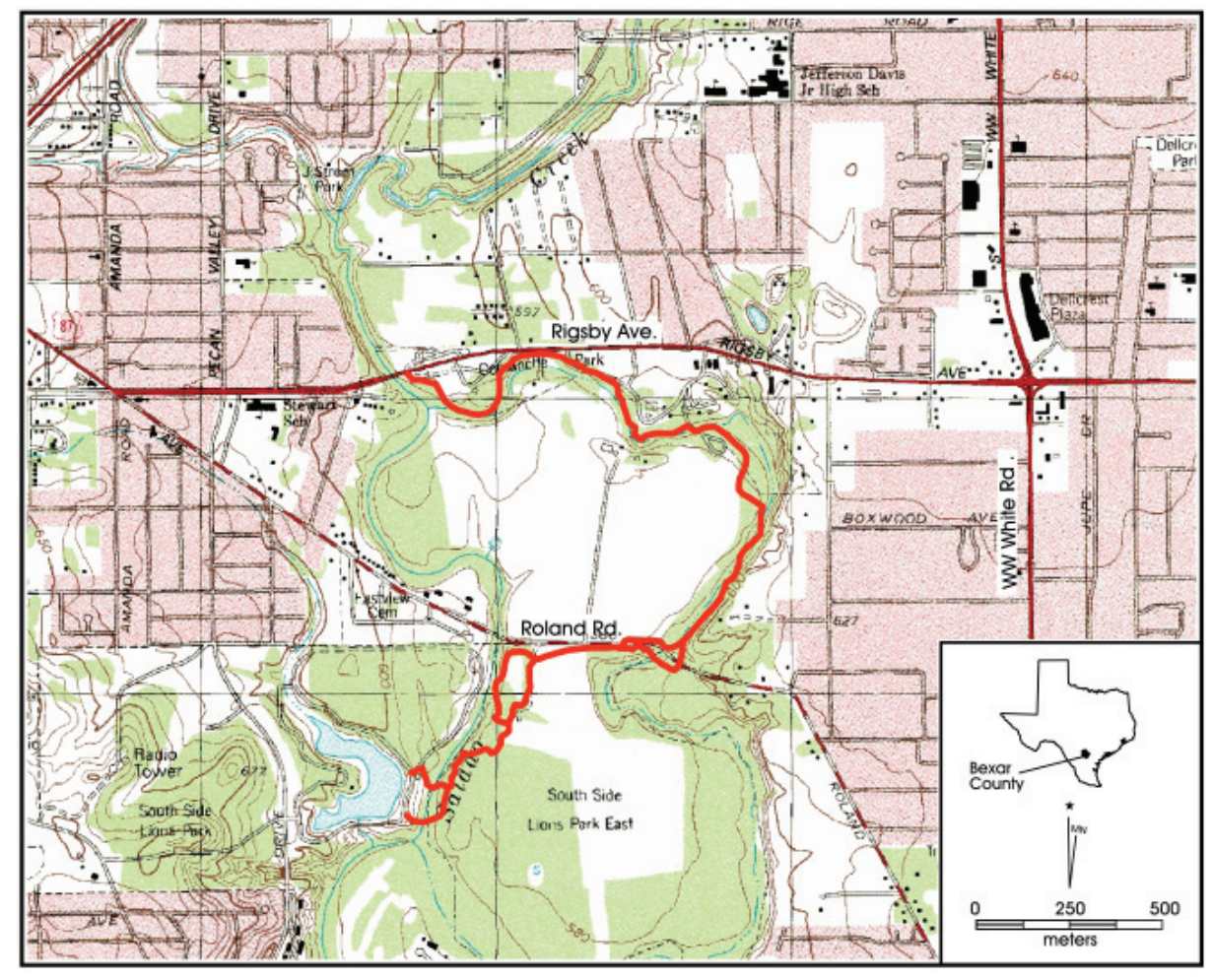

Figure 1-1. The location of the project area on San Antonio East 7.5 Minute Series U.S.G.S. Quadrangle maps. 
new archaeological site was identified 41BX1756. It will be discussed in detail in Chapter 4. Specific recommendations regarding this site will be discussed in detail in Chapter 5 .

This document summarizes the results of the fieldwork and provides recommendations regarding the management of the cultural resource located on the project area. This report is organized into five chapters. Chapter 2 provides an overview of the project area with specific reference to its historical importance; in addition, it summarizes previous archaeological work relevant to the project. Chapter 3 discusses the fieldwork and laboratory methodology employed during the project. The results of the archaeological survey are presented in Chapter 4 . Chapter 5 summarizes the work and provides recommendations for the South Salado Creek Greenway project. Appendix 1 is a detailed account of Austin's encampment along Salado Creek prior to the Battle of Bexar in the present-day Comanche and Covington Parks. 


\section{Chapter 2: Background Information}

This chapter presents a brief description of the South Salado Creek Greenway project and characterizes the environment and cultural history of the project area. The chapter concludes with a summary of the previous archaeological work conducted in the vicinity of the project area.

\section{The Project Area}

The project area is within the Salado Creek watershed in north-central San Antonio bordered by Rigsby Avenue to the northwest and Southside Lion's Park East to the south. Roland Road bisects the project area from the east to the west (see Figure 1-1). The project area proper represents a linear stream channel and its immediately adjacent floodplain and low-lying terrace deposits. It consists of an alignment approximately two and three-tenths miles (3701 meters) long running through two adjoining county parks, recently acquired property within the watershed, as well as former agricultural lands (See Figure 2-1). The ROW is approximately 4 meters in width, though it varies in different locations of the project area.

\section{Project Environment}

The immediate project area is a riparian environment that Potter et al.(1995) term the Middle Salado watershed. It consists of approximately 25 linear $\mathrm{km}$ of drainage from the confluence of Panther Springs and Salado creeks to roughly $20 \mathrm{~km}$ above the Salado/San Antonio River confluence (Potter et al. 1995). The Middle Salado contrasts to the Upper Salado watershed through its decrease in elevation and stream gradient, increased stream meandering and different geomorphology (Potter et al. 1995). Landforms in this portion of the Salado Creek consist of broad floodplains with deeper alluvial deposits and terrace landforms (Potter et al. 1995). The project area lies within the Blackland Prairie region of Texas. Presently, the majority of this land is dedicated to agricultural use (Taylor et al. 1991). Prior to the arrival of Europeans, the Blackland Prairie is described as near level to gently rolling hills and valleys, with mottes crossed by large rivers with narrow riparian environments (Gould 1975). The Blackland Prairie supported a tallgrass prairie with little bluestem (Schizachyrium scoparium) dominant, and big bluestem (Andropogon gerardi), switchgrass (Panicum virgarum), and grama (Bouteloua sp.) constituting major species (USDA 1981). Riparian vegetation consists of oaks (Quercus sp.), elm (Ulmus $s p$.), hackberry (Celtis $s p$.), pecan (Carya illinoiensis), with an understory consisting of buffalo grass (Buchloe dactyloides), Indiangrass (Sorghastrum nutans), grama (Bouteloua sp.), tall dropseed (Sporobolus asper), and Texas wintergrass (Stipa leucotricha) (Gould 1975).

The soils in the immediate vicinity of the active channel are described in the USDA Soil Survey as Frio ( $\mathrm{Fr}$ ) and Venus $(\mathrm{VcB}, \mathrm{VcC})$ series (Taylor et al. 1991). The Frio series is an alluvial clay loam with moderate depth and is found in the floodplains of the Salado Creek. The Frio soils along watersheds are frequently flooded and poorly drained with a high capacity to hold water (Taylor et al. 1991). The Frio soils are found in Covington, Comanche parks and Southside Lions Park East of the project area. The Venus series is a clay loam that generally occurs as a transition between the upland terrace and the floodplain of the Salado Creek on slopes ranging from 1 to 5 percent. This soil type is found between Roland Avenue and the area south of Comanche Park. The $\mathrm{VcC}$ and $\mathrm{VcB}$ soils have relatively thin surface layer of approximately 14 inches, with a deep subsurface layer of approximately 20 inches (Taylor et al. 1991).

Average annual rainfall is between 750 to $1,150 \mathrm{~mm}$ with the majority of the precipitation falling in spring and early fall (Taylor et al. 1991). Average annual temperature ranges between 17 to $21^{\circ} \mathrm{C}$ (Taylor et al. 1991). Climate in this general area is classified as humid subtropical with hot, humid summers and mild, dry winters (Taylor et al. 1991).

\section{Culture History}

The project area lies within a region where archaeologists commonly use the chronologies of South and Central Texas to describe the prehistoric context (Collins 1995; Hester 1995). San Antonio has a rich history illustrative of the early epoch of Texas. We examine in detail two aspects of this history that emphasize the development of San Antonio during the early $19^{\text {th }}$ century. First, the roads leading to San Antonio that connected to other towns of Texas, and second, the economic redistribution and change that occurred after the Texas Revolution in the form of headright grants.

\section{Prehistoric Periods}

Bexar County contains a rich prehistoric archaeological record that begins approximately 9000 B.C. and ends approximately A.D. 1700. There are three commonly accepted periods that 

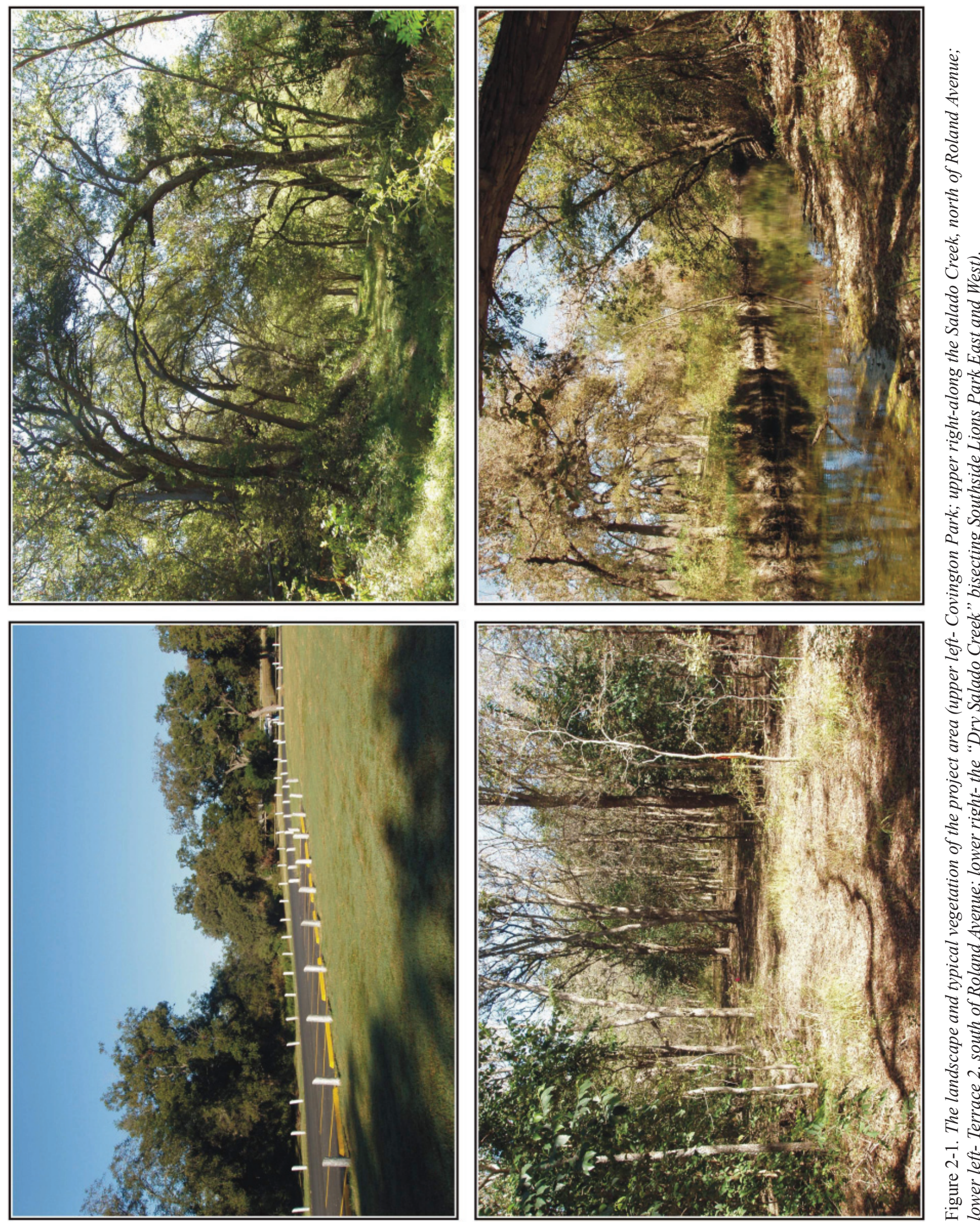
describe changes in the technological and material culture of hunter- gatherers. These periods are the Paleoindian (ca. 10,000 B.C. to 7000 B.C.), the Archaic (ca, 7000 B.C. to A.D. 800), and the Late Prehistoric (ca. A.D. 800 - 1700).

Material culture from the Paleoindian period is characterized by Clovis and Folsom fluted projectile points used to hunt megafuana, such as mammoth and bison (Bison antiquus). The Richard Beene site (41BX831) is an example of a site with a Paleoindian occupation located in the near vicinity. Along the Salado Creek watershed, a significant Paleoindian site (41BX229) is located at St. Mary's Hall's School with projectile types that are distinctive of a later Paleoindian period and marking a transition to the Archaic Period (Hester 1978).

In general, the Archaic Period is well represented in Bexar County. This period encompasses the longest span of time from $6000 \mathrm{BC}-\mathrm{AD} 700$, and is generally divided into three sub-periods, the Early, Middle and Late Archaic. It is characterized by adaptations to changing environment, resources, increase in population density, and a broader array of material culture. Intensification of subsistence resources is a hallmark of this period that included the use of features such as hearths, ovens, and burned rock middens. The Granberg site (41BX17), is located along the Salado Creek.

The Late Prehistoric period (AD700 - AD1700) is distinguished by material culture that includes the adoption of ceramics and the bow and arrow. Changing environment caused by climate shifts marks a change in the availability of resources. Late Prehistoric material culture such as projectile points and ceramics are commonly found on the surface and/ or shallowly buried.

\section{Historic Period}

While the Spanish visited the San Antonio region, it was not until the early 1700's that Europeans began to actively settle the surrounding region of what would become San Antonio de Béxar (Bannon 1974). The European expansion coincided with the southward migration of the Comanche and Apache displacing many of the area's indigenous groups (T.N.Campbell 1979; Newcomb1961). The formal beginning of the city of San Antonio with the establishment of San Antonio de Béxar Presidio in 1718 and San Fernando de Béxar Church in 1731 (Handbook of Texas Online 2007). Five missions were built between 1718 through 1731 and some Native Americans groups moved to the protective environment of the various missions that were established in the area in the early eighteenth century. The move to the missions significantly altered the hunter-gatherer way of life and the material culture of many of these groups (T.N.Campbell 1979; Newcomb1961). By 1773, the population of Europeans, mestizos and converted Native Americans was estimated at 2,060 (Handbook of Texas Online 2007). San Antonio, because of its political, economic, and logistical significance, was the site of conflict first between Mexico and Spain, followed by Mexico and Texans/Tejanos and finally, Mexico and the United States during the first half of the nineteenth century.

\section{Historic Trails and Roads}

The early roads connecting San Antonio to neighboring towns and regions were typically little more than dirt tracks through woods and across prairies. Early regional roads followed relatively direct courses that incorporated trails used by game, Indians, cattle, and later, Spanish and Mexican rancheros (Hadley et al. 1997). Transportation on the rough, eighteenth and early nineteenth-century trails was possible only on foot, on horseback, or by mule or oxen train (R.B.Campbell 2003:211). As travel increased, many trails became wagon roads in the mid-nineteenth century (R.B.Campbell 2003:211).

Several noteworthy early historic roads crossed Salado Creek east of San Antonio including the Camino Real de los Tejas (later the Austin Road), the Old Seguin Road, the Old Gonzales Road and at least two routes of the Goliad or BéxarLa Bahia Road. Two of these, the Gonzales Road and the New Goliad Road crossed Salado Creek within the current project area.

\section{History of the Goliad Road}

The development of the Goliad, or Béxar-La Bahía Road, followed the relocation of Presidio La Bahía and Mission Espiritu Santo into the San Antonio River Valley in 1749. The road followed the San Antonio River closely and seldom varied more than a mile or two from the river (Austin 1830). As the road approached San Antonio, it crossed Salado Creek just below the confluence with Rosillo Creek and entered San Antonio in the vicinity of the modern I-37/IH-10 interchange (Texas General Land Office, n.d.).

Initial use of the early route was by Franciscan missionaries and presidio soldiers to maintain order and control of the northeastern provinces of New Spain (Hadley et al. 1997). By the mid-eighteenth century, the road served the needs of Spanish ranches that filled the San Antonio River valley from Béxar to La Bahía (J. Jackson 1986). The road continued to 
flourish into the Mexican period and was used as a route for military operations during both the Casas Revolt (1811-1813) and during the Texas Revolution (1835-1836) (Almaráz 1971, Winders 2004).

What would become known as the Chihuahua Road and merge into the Old Goliad Road was discussed as early as 1829 by Stephen F. Austin and ultimately came into being during the Mexican-American War (Swift and Corning 1988:44). Its route was dictated by the need to re-supply troops and the logistic importance of San Antonio and the coastal port depots to the southeast (Tomka et al. 2004, Francell 2007). This road would eventually become a route for westward expansion into Texas, Mexico, and eventually California (Tomka et al. 2004:31; Francell 2007). At the height of business along the Chihuahua Road, more than 200 businesses used the route through San Antonio (Francell 2007). Several alternate routes developed along the Chihuahua Road between San Antonio and the coast. One of these roads passed from Indianola through Victoria, but rather than swinging south through Goliad, the route continued northwesterly passing through the communities of Riddleville and Cuero. Another route, developed sometime just prior to 1846, angled even farther north passing from Victoria and Yorktown to Seguin and then westward to San Antonio (Swift and Corning 1988:130131).

While the earliest routes of the Goliad Road approached San Antonio de Béxar from the south-southwest, variations on this route were clearly in use by the mid-nineteenth century. A map surveyed and drawn in 1876 by W. H. Owen details a northern route and notes that the "New Goliad Road" was established in 1854 (Owen 1876). Dotted lines drawn paralleling and/or crossing this new route and labeled "presently traveled route" illustrate trails and roads in use prior to 1854 . The principal route, located approximately three miles north of the SaladoRosillo Creek confluence, maintained a northwest/southeast direction and merged with the Gonzales Road west of Salado Creek near modern Rigsby and Roland Avenues.

The question remains as to when and why this northerly route (New Goliad Road) came into use and how much traffic it shifted away from the older more southwestern route? It is clear that the old Goliad Road was still a thoroughfare in 1846 when Captain Lorenzo Sitgreaves of the Corps of Topographical Engineers traveled and reported on that route (Hughes 1846:49). Sitgreaves kept notes pertaining to the route's landmarks and mileages, and recorded that after paralleling the San Antonio River and crossing Salado Creek, it was nine miles to San Antonio de Béxar (Hughes 1846). Checking modern maps of the area, it is approximately nine linear miles from the Rosillo-Salado confluence to the center of San Antonio, while it is only a little over four miles from the city center to the New Goliad crossing of the Salado.
Therefore, it is clear that it was the lower route which was used by General Wool's army during the march from Lavaca to Bexar and likely throughout the Mexican War (18461848).

\section{History of the Gonzales Road}

The route that would become the Gonzales Road was surveyed in 1827 to link the Anglo settlements of Austin's and DeWitt's colonies to the garrisoned town of San Antonio de Béxar (Jackson 2000:210). When completed, the road was 65 leagues, or 169 miles, long and was broad enough for wide wagons (Jackson 2000:210). Soon after the establishment of this new route, Manuel de Mier y Terán traveled the route and described the road in the vicinity of the Salado.

\section{Sunday, April 13, 1828}

At 4:01 PM., departure from Béjar: 15-minutestop at the guard post. At 5 P.M. arrival at the Salado (Creek). One league of level road east through the hills: vegetation very thick with grasses and plants of the genus gaura and verbena, and a liliaceous plant that senior Berlandier called narciso. Camp on the west bank of the Arroyo del Salado. This is small stream runs deep between two small hills. Along its entire length there is a forest of oak, pecan, plum, elm? and cottonwood trees. Its source is to the northwest of Béjar, six leagues from this site on the Salado, and it flows into the Béjar (San Antonio) River onehalf league above the Espada Mission. At night much calling of the local tiburón, rana taurina (bullfrog), singing of owls, and another very strange song that sounded like a cuckoo to $\mathrm{Mr}$. Berlandier.

Monday, the 14th.

From the Arroyo Del Salado to the Cibolo. From 7:25 until 1:25 we traveled through the hills. In crossing the valleys they form, there are streambeds so deep and narrow that they are very dangerous for the carriages. It is said that the North Americans have opened the road, but there is scarcely more than a path and distances markings on the trees. (Jackson 2000:43)

The Gonzales Road was the center of a great deal of military activity during the Texas Revolution as a conduit for Texan troops and couriers to and from the Anglo settlements of Gonzales and beyond (e.g., Barr 1990, Winders 2004). Within the current project area and adjacent to the Gonzales Road in Covington Park, was the location where Stephen F. Austin's 
Texan Army camped for one week (Oct 1835) during the Siege of Bexar (Barr 1990). Appendix 1 recounts the brief record of this episode. The route was also used by Susanna Dickinson, wife of slain Alamo defender Almeron Dickinson, immediately following the fall of the Alamo (R.Jackson 1997:111-116). Santa Anna spared Mrs. Dickinson's life and sent her along the road to tell colonists 65 miles away at Gonzales the fate that had befallen the Texans (R.Jackson 1997:111-116).

Beginning on March 11, 1836, the Gonzales Road also carried Santa Anna's First Division, including seven hundred infantrymen, two pieces of artillery, and a month's rations eastward toward Gonzales at the outset of the Runaway Scrape (de la Peña 1975). Fourteen days later, Santa Anna and his staff, including General Filisola, departed along this same road during a period of cold heavy downpours. José Enrique de la Peña, famous for his controversial account of the death of Davy Crockett, also traveled with his general and recorded that the Gonzales Road between the Salado and Cibolo Creek was all but impassable due to several violent afternoon thunderstorms which made the march cumbersome (de la Peña 1975).

The road as depicted on maps (Rullmann 1887) from the 1880 s, left San Antonio by way of Alameda Street (today Commerce Street) and forked toward the south in the vicinity of modern South Walters and Hedges Streets, adjacent to modern St. Phillips College. The route then dropped south and bent gradually towards the southeast where it forked again near modern Rigsby and Roland Avenues into the New Goliad Road and the Gonzales Roads. The Gonzales Road, almost thirty years older than the New Goliad Road, continued east toward the Salado where it crossed into modern Covington Park and continued east crossing Cibolo Creek below its confluence with Martinez Creek.

\section{Headright Land Grants}

The period following the Texas Revolution, from 1837 to the incorporation of Texas into statehood, marks a tumultuous political and economic period. Prior to 1837 , land ownership was under a Spanish/Mexican system called derechos or rights (Montejano 1987:50; Pitts 1966). Wealth was based upon land, belonged to family lineages and was fixed, in essence, creating a class of landed gentry (Montejano 1987:50). This system contrasts with the "mercantile" system of newly arrived Anglo- Americans that saw land as a commodity to be bought and sold (Montejano 1987:50). The project area and the lands associated with it are part of this history.

The Republic of Texas Constitution of 1836 had a provision that all who were in Texas during the revolution and did not provide aid to the Mexican government were entitled to land ownership known as headright grants (Hogan 1975:10; Montejano 1987:51-52; Pitts 1966). Under this provision, heads of households were entitled to one league and labor of land (a total of 4605 acres); unmarried men were allotted one third of a labor (approximately 29 acres) (Pitts 1966:5). While subsequently modified as a more settlers arrived in Texas, this provision remained in effect until 1844 (Hogan 1975:11).

In Figure 2-2, maps show the headright grants established after 1836 and ownership by John W. Smith after 1837 within the project area. The project area consists of two headright grants: one to the family of Ignacio Perez, and the other to Maria Gertrudis de Alaniz. The Perez grant consists of the majority of the Comanche and Covington parks areas while the de Alaniz grant is for everything south of these parks. The Perez grant was lost in 1851 through court rulings that invalidated the family ownership of this land (Weston et al. 2004a, referenced in McGraw and Hindes 1987:110-111). The de Alaniz grant was bought by John W. Smith in 1837 (Bexar County Historical Records 2007). Smith eventually became one of the largest land buyers in San Antonio, individually buying an estimated 123,391 acres of land and in partnership an additional 41,445 acres (Pitts 1966:29).

The buying and selling of headright grants was and remains a debatable affair of early Texas history. It was described as an "unholy dictation of speculators and marauders of human rights," by then President Samuel Houston (Pitts 1966:5). While characterized as legalized land grabbing by newly arrived Anglo-Americans, buyers included men like Smith, who had long and significant ties to the community of prerevolutionary San Antonio. It was also a business affair that prominent Tejanos, such as Juan Seguin and José Navarro, practiced although to a lesser degree (Montejano 1987:2627; Pitt 30-32). Economically, it began the process of change from the familial ownership of land to the Anglo-American merchant economy. The transition certainly created injustices, through a class of dispossessed land owners such as Ignacio Perez (Weston et al. 2004a). The period coinciding with the headright grants marks the political ascent and control by Anglo-Americans of the newly formed economic and political institutions of San Antonio and Texas from Tejanos and Mexican interests (Montejano 1987; Pitts 1966; Weston et al. 2004a).

The land known as the de Alaniz tract was divided and lots were sold after Smith's death in 1845 to pay off debt (Bexar County Historical Records 2007). Maria Jesus Curbelo Smith, the widow of John W. Smith, retains control of what became the Southside Lion's Park East Park; she remarried James B. Lee (Chabot 1937:157). This portion remained in the Lee family until 1907 when it was sold to J.D. Guinn 

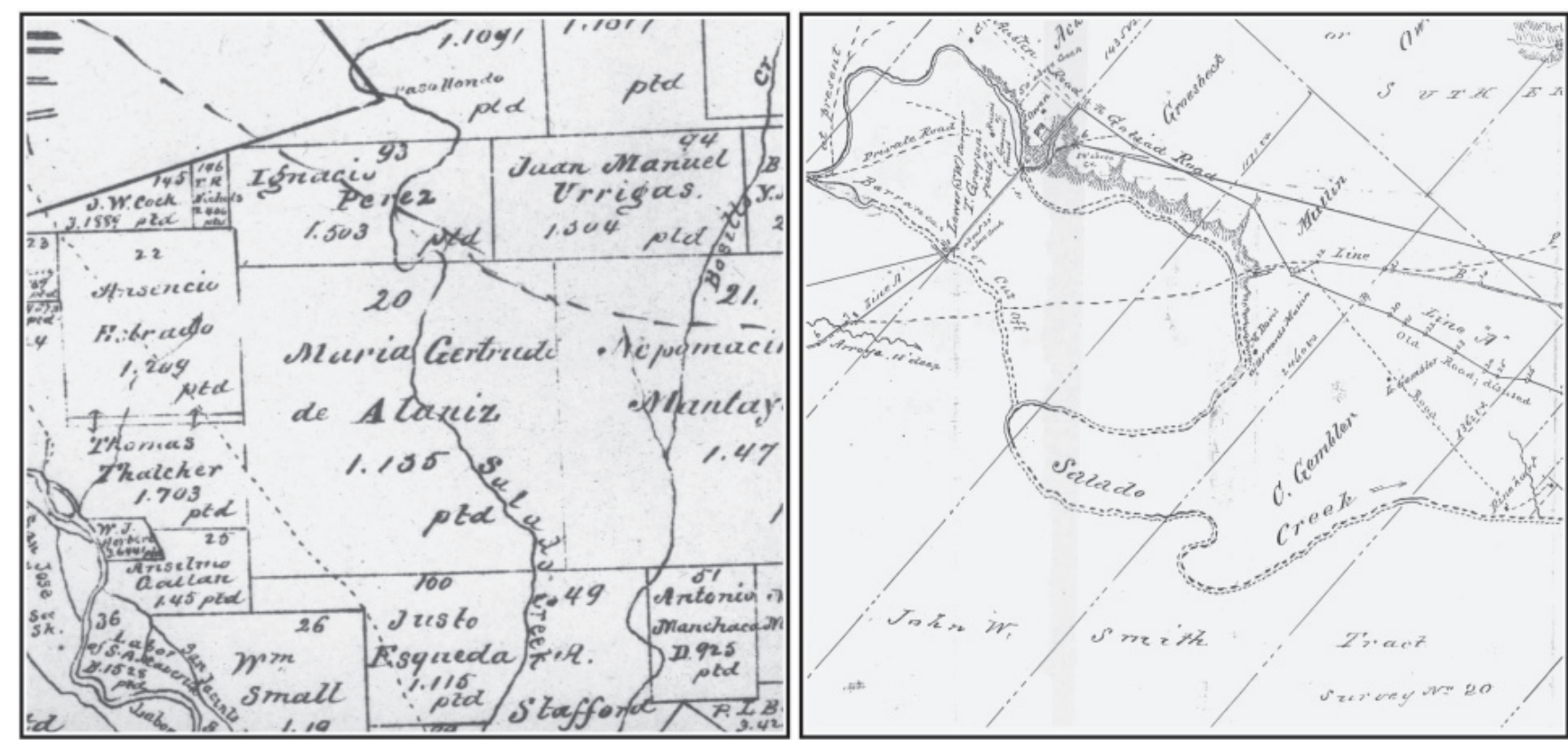

Figure 2-2. Detail of 1876 Owen map showing land ownership prior to 1837. Detail of "New Goliad Road Map" showing White's ownership after 1837. Note reference to the original "Survey No. 20" in both maps.

(Bexar County Historical Records). Guinn sold the land to George Brackenridge in 1917; his estate in turn sold the land to City of San Antonio in 1964 (Bexar County Historical Records 2007).

\section{Previous Archaeological Investigations}

A background literature review revealed only one archaeological investigation to date within the vicinity of the project area. In 2002 and 2003, CAR-UTSA conducted archaeological and geoarchaeological investigations along Salado Creek from East Houston Street and terminating immediately north of the current project area in the northeast section of Comanche Park (Weston et al. 2004b). Both shovel testing and backhoe trenches revealed no significant archaeological deposits. Eight backhoe trenches were excavated along the Salado Creek. Backhoe trenches contained for the most part recent sedimentary deposits and debris less then 20 years old (Weston et al. 2004b: 28-29). 


\section{Chapter 3: Field and Laboratory Methods}

As part of the archaeological services provided to RVK Inc., and in accordance with the Texas Historical Commission guidelines, the Center for Archaeological Research was contracted to conduct the following fieldwork: 1) complete a linear intensive pedestrian survey accompanied by shovel testing of the 2.3 mile (3701 m) alignment, and 2) if necessary, augment the survey with mechanically excavated backhoe trenches to investigate any deposits that cannot be effectively explored using shovel testing. This chapter presents the field and laboratory methods used during the archaeological investigations of the South Salado Creek Greenway Project.

\section{Field Methods}

The project area consists of approximately 2.3 miles of active channel, floodplain, and terraces within the portion of the Salado watershed located between Rigsby Avenue and into Southside Lions Park East in south-central San Antonio. A preliminary visit of the project area indicated that the majority of the survey area has not been impacted by developments. A combination of methods were proposed for the survey of the South Salado Creek Greenway including pedestrian surface reconnaissance, shovel testing, and contingent upon shovel testing results, backhoe trenching. Shovel testing was to be employed prior to backhoe trenching in order to determine the depth of soil deposits as well as the horizontal and vertical distribution of any cultural material in the project area.

\section{Pedestrian Survey and Shovel Testing of the Alignment}

The archaeological investigation of the alignment consisted of an intensive pedestrian survey. Based on the alignment length (approximately 2.3 miles), the testing required to fulfill the THC minimum survey standards for linear projects less than 30 meters wide would consist of a minimum of 43 shovel tests (ST), with a density of 16 ST per mile. Shovel test locations were evenly distributed in $100 \mathrm{~m}$ segments along the ROW on the floodplain and terraces abutting the active channel. UTM coordinates for these 43 locations were determined, and uploaded into Trimble Geo XT GPS units prior to the CAR's commencement of fieldwork. Shovel tests were located in the field using the GPS map feature. Shovel tests were $30 \mathrm{~cm}$ in diameter, and when possible, extended to a depth of $60 \mathrm{cmbs}$. They were excavated in $10-\mathrm{cm}$ increments, and all soil from each level was screened through $1 / 4$-inch hardware cloth. All encountered artifacts were recorded with appropriate provenience for further laboratory processing, analysis, and curation. A shovel test form was completed for every excavated shovel test. Data collected from each shovel test included the final excavation depth, a tally of all materials recovered from each $10-\mathrm{cm}$ level, and a brief soil description (texture, consistency, Munsell color, inclusions). Shovel test locations were sketched onto aerial photographs as a backup to GPS provenience information. Any additional observation considered pertinent to the investigation was included as comments on the standard shovel test excavation form.

\section{Backhoe Testing}

There are three planned creek and drainage crossings where construction within the APE could potentially impact to a depth beyond that of shovel testing $(60 \mathrm{cmbs})$. If during the pedestrian survey the Project Archaeologist determined that deep soils (> $60 \mathrm{cmbs}$ ) were present in these locations, then investigations at these crossings were to be augmented by backhoe trenches (BHTs). If warranted, a maximum of six BHTs were proposed to investigate deposits that could not be effectively explored using shovel testing. To comply with the Minimum Survey Standards as defined by the THC, each trench was to measure approximately one meter in width and five meters in length. If any discrete, potentially intact, significant prehistoric features or deposits were detected in the backhoe trenches, they were to be fully exposed, sampled (i.e., charcoal samples; 1-3-liter matrix samples), and recorded (i.e., profiled, photographed, scaled drawing).

\section{Site Recording and Identification}

For the purposes of this survey, a locality must contain a certain number of cultural materials or features that are at least 50 years old within a given area that would define it as an archaeological site. The definition of a site used for this project was as follows: (1) Five or more surface artifacts within a 15 -meter radius (ca. $706.9 \mathrm{~m}^{2}$ ), or (2) a single cultural feature, such as a hearth, observed on surface or exposed in shovel testing, or (3) a positive shovel test containing at least three artifacts within a given $10-\mathrm{cm}$ level, or (4) a positive shovel test containing at least five total artifacts, or (5) two positive shovel tests located within 30 meters of each other, or (6) a buried cultural feature, such as a hearth, exposed in a backhoe trench, or (7) a buried surface containing cultural material exposed in a backhoe trench.

The boundary of any newly documented site was to be plotted on an aerial photograph and its location recorded with 
a Trimble GeoXT GPS unit. A datum was to be placed within the site and recorded with the GPS unit. In addition, any other significant features of the site, such as fences and drainages, were to be mapped with the GPS unit. A sketch map of the site was to be produced to serve as a backup for the GPS data. Digital photographs were to be taken of the site. All pertinent Texas archaeological site forms were completed and submitted to the THC to obtain a site trinomial.

\section{Archaeological Laboratory Methods}

Cultural materials and records obtained and/or generated during the project were prepared in accordance with federal regulation 36 CFR part 79, and THC requirements for State Held-in-Trust collections. Additionally, the materials are curated in accordance with current guidelines of the CAR. Artifacts processed in the CAR laboratory were washed, air-dried and stored in 4-mm zip locking archival-quality bags. Materials needing extra support were double-bagged. Acid-free labels were placed in all artifact bags. Each label contained provenience information and a corresponding lot number written in archival ink, with pencil or laser printed. Tools were labeled with permanent ink over a clear coat of acrylic and covered by another acrylic coat. Artifacts were separated by class and stored in acid-free boxes. Boxes were labeled with standard labels. Digital photographs were printed on acid-free paper and labeled with archivally appropriate materials and placed in archival-quality sleeves. Field notes, forms, photographs, and drawings were printed on acid-free paper and placed in archival folders. A copy of the survey report and all computer disks pertaining to the investigations were stored in an archival box and curated with the field notes and documents. All cultural materials and records are permanently curated at the CAR facility. 


\section{Chapter 4: Survey Results}

The pedestrian survey of the South Salado Creek Greenway project was completed between 24- 26 October 2007 with additional testing on 5 November 2007. This chapter provides detailed information of that archaeological investigation including the shovel test findings, and the rationale for the exclusion of backhoe trenching of the creek crossings. One multi-component site was identified and recorded. In addition, post-field investigation, archival research suggested that historic roads crossed the project area. This aspect was investigated and is presented herein.

\section{Shovel Tests}

Of the forty-three planned shovel tests along the alignment, forty were excavated (Figure 4-1). ST8 and ST9 were not excavated because their locations fell within an asphalted trail. ST 43 was located in the Salado Creek floodplain and was terminated at $30 \mathrm{cmbs}$ due to the presence of alluvial gravels. The project area and placement of shovel testing is divided into two primary settings; the floodplain of the Salado Creek and the adjacent terraces of the Salado Creek drainage. Shovel tests located in the floodplain (T-0) are those located north of Roland Avenue. These shovel tests contained deep sediments as the result of periodic flooding events. The soils were fairly homogenous and consisted of medium brown, silty clay overlying brown, compact to hard, silty clay. These shovel tests contained modern debris, small pebbles, gravels, and shell fragments throughout the $60 \mathrm{~cm}$. No cultural artifacts, prehistoric or historic, were found in the shovel tests in this setting. The shovel tests excavated south of Roland Avenue, with the exception of the two dug in Southside Lion's Park West, were located on terraces (T-1 and T-2) of the Salado Creek drainage. Noting that exception, all other shovel tests consisted of deep sedimentary deposits, typically brown to dark brown silty clay or reddish brown silty clay. The soil in this area was well developed and undisturbed to $60 \mathrm{cmbs}$ as evidenced by calcium carbonate and lack of modern debris and/or sediment. During the survey, three shovel tests along the APE contained prehistoric cultural material; all were found south of Roland Avenue in this setting. ST29 contained one piece of burned rock at a depth of $30-40 \mathrm{cmbs}$. Its location was further tested by two additional shovel test that were negative for cultural materials. ST36 is approximately $5 \mathrm{~m}$

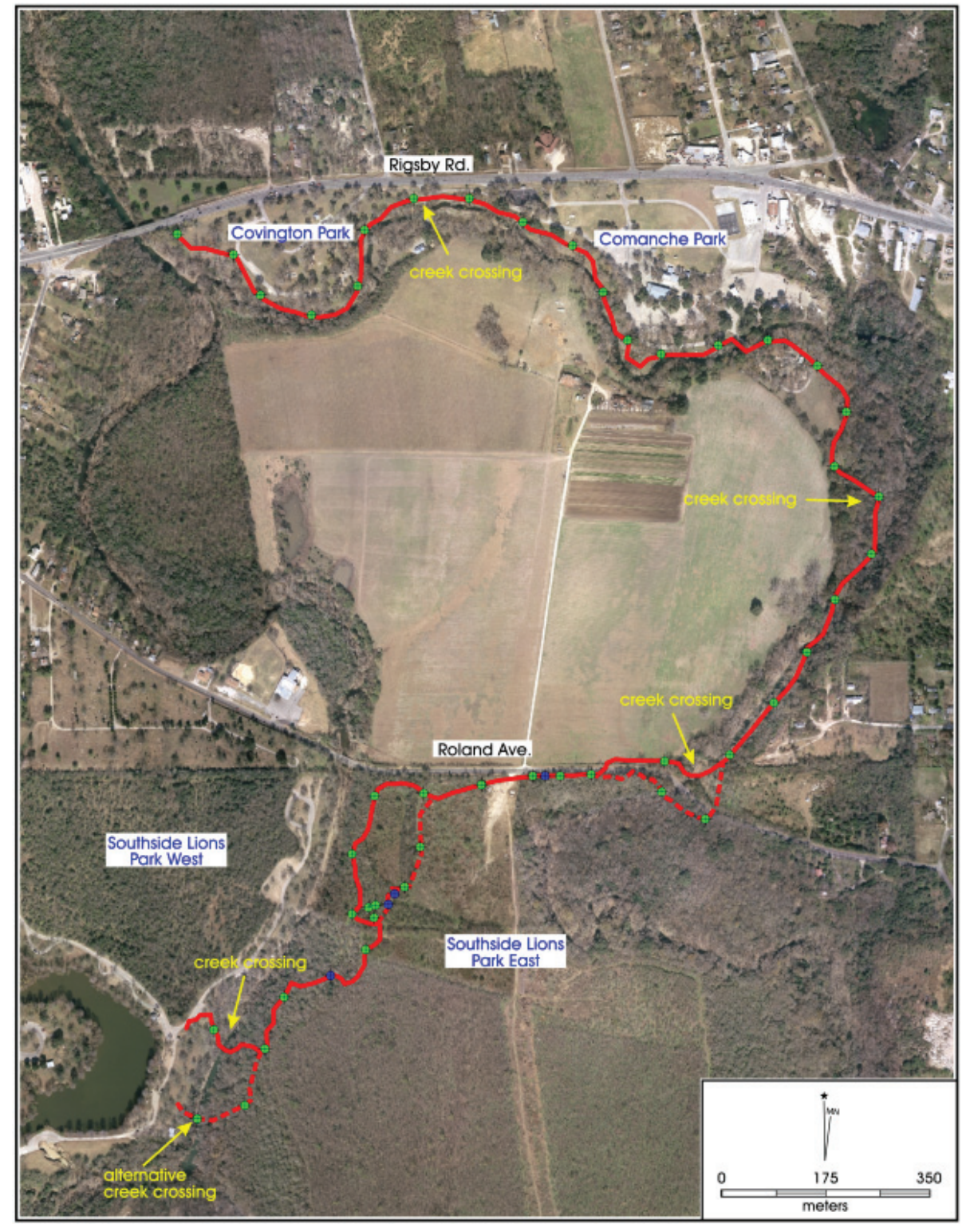

Figure 4-1. The project area depicted on 2005 photograph with shovel test locations (primary route is in red and alternative route is marked by red dashed line). 
northeast of a concrete foundation and contained a historic/ modern artifact, burned rock and debitage. It formed the basis for the prehistoric component of the archaeological site and will be discussed in the next section.

\section{BX1756}

41BX1756 is a multi-component site having both historic and prehistoric cultural materials. Figure 4-2 shows the boundary and location of 41BX1756. It is located in the southern portion of the project area and is approximately $330 \mathrm{~m}^{2}$.

The historic component consists of the cedar pier foundation of a house, a fence line and an adjacent concrete structure. This component dates to the early twentieth century based upon its appearance on an aerial photograph taken in 1937

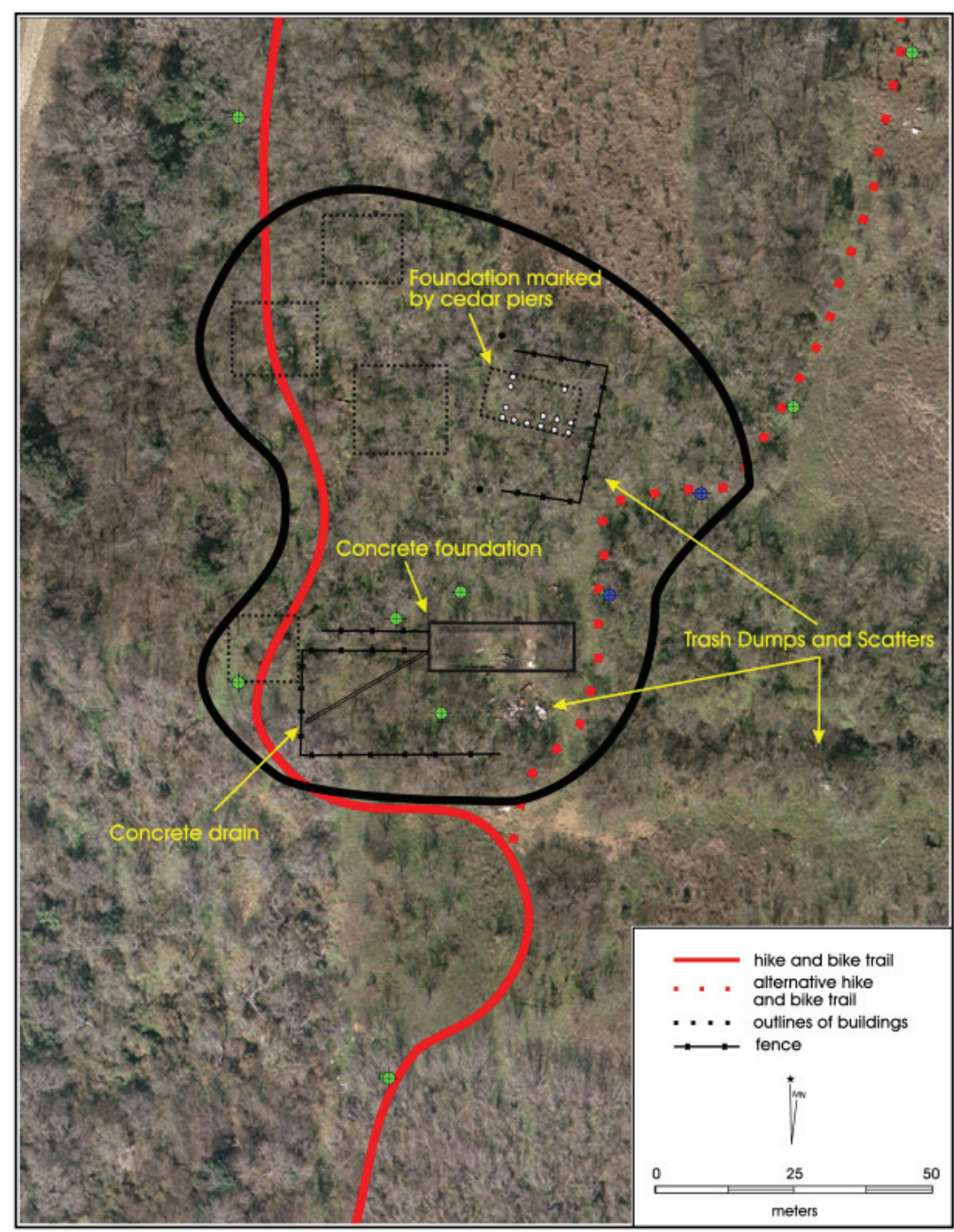

Figure 4-2. The extent of 41 BX1756 demarcated by solid black line.
(Tobin Aerial Survey), and its exclusion from the 1903 USGS map. The construction of the house suggests that it was built in the 1920's or 1930's. The concrete structure is approximately $176 \mathrm{~m}^{2}$ in size standing $80 \mathrm{~cm}$ high, divided into one main room and four sub-rooms (see Figure 4-3). Figure 4-4 and Figure 4-5 show architectural detail of this structure. Other auxiliary structures noted on the 1937 aerial and 1953 USGS map (Figure 4-6) no longer exist. Both the house and concrete foundation were destroyed in a fire at an unknown date. 41BX1756 was delineated using the georeferenced 1953 USGS map to include the totality of the homestead.

Historically, the land surrounding the site served agricultural purposes, and based upon all available data, 41BX1756 also functioned in this capacity. Mr. Anthony Granieri, a longtime inhabitant of the area and local farmer, recalled the property was originally a dairy farm (Personal Communication 7 November 2007). It is assumed that the concrete foundation served as a facility related to dairy production based on this discussion.

A shovel test (ST36) approximately 5 meters northeast of the concrete foundation was positive for prehistoric material. Three pieces of debitage and several pieces of burned rock were found at 20- $40 \mathrm{cmbs}$ in this shovel test. Six shovel tests were placed in the vicinity of this positive shovel test. Four shovel tests south and west of the positive shovel test were negative for any cultural materials (see Figure 4-2). A fifth shovel test, ST48, north of ST36 was positive and marks the known northern extent of the prehistoric component.

\section{Backhoe Trenching}

There are four planned creek crossing (Figure 4-1) where construction could potentially impact subsurface features beyond the excavated depth of shovel testing $(60 \mathrm{cmbs})$. As initially planned, investigationsthese areas would be augmented by mechanically excavated backhoe trenches (BHTs), if warranted. Shovel tests placed in the vicinity of the crossings revealed modern sediments to depth of $60 \mathrm{cmbs}$. These sediments did not have calcium carbonates indicative of soil formation, contained modern artifacts and/or contained large alluvial gravels. In a previous archaeological investigation 


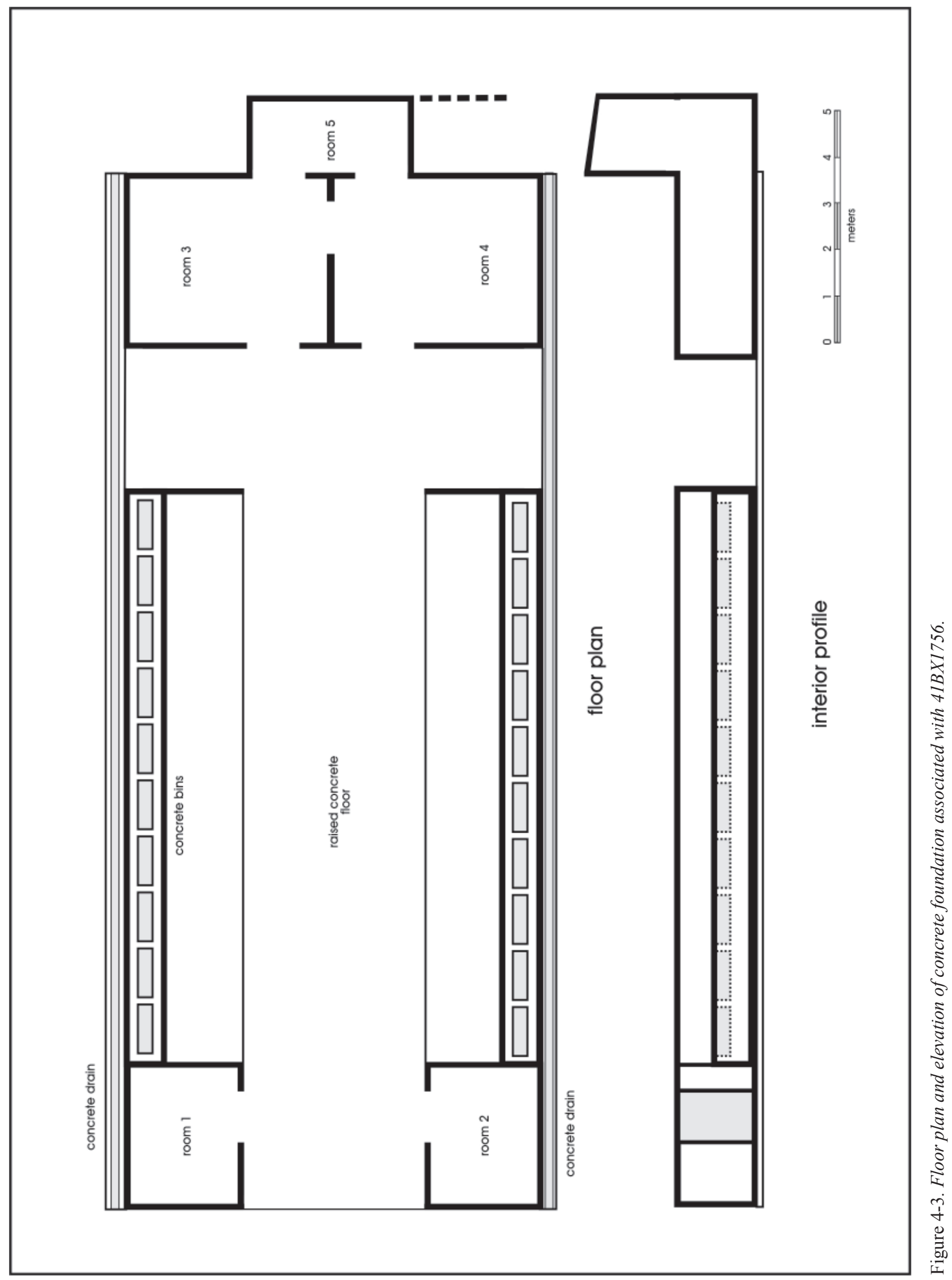



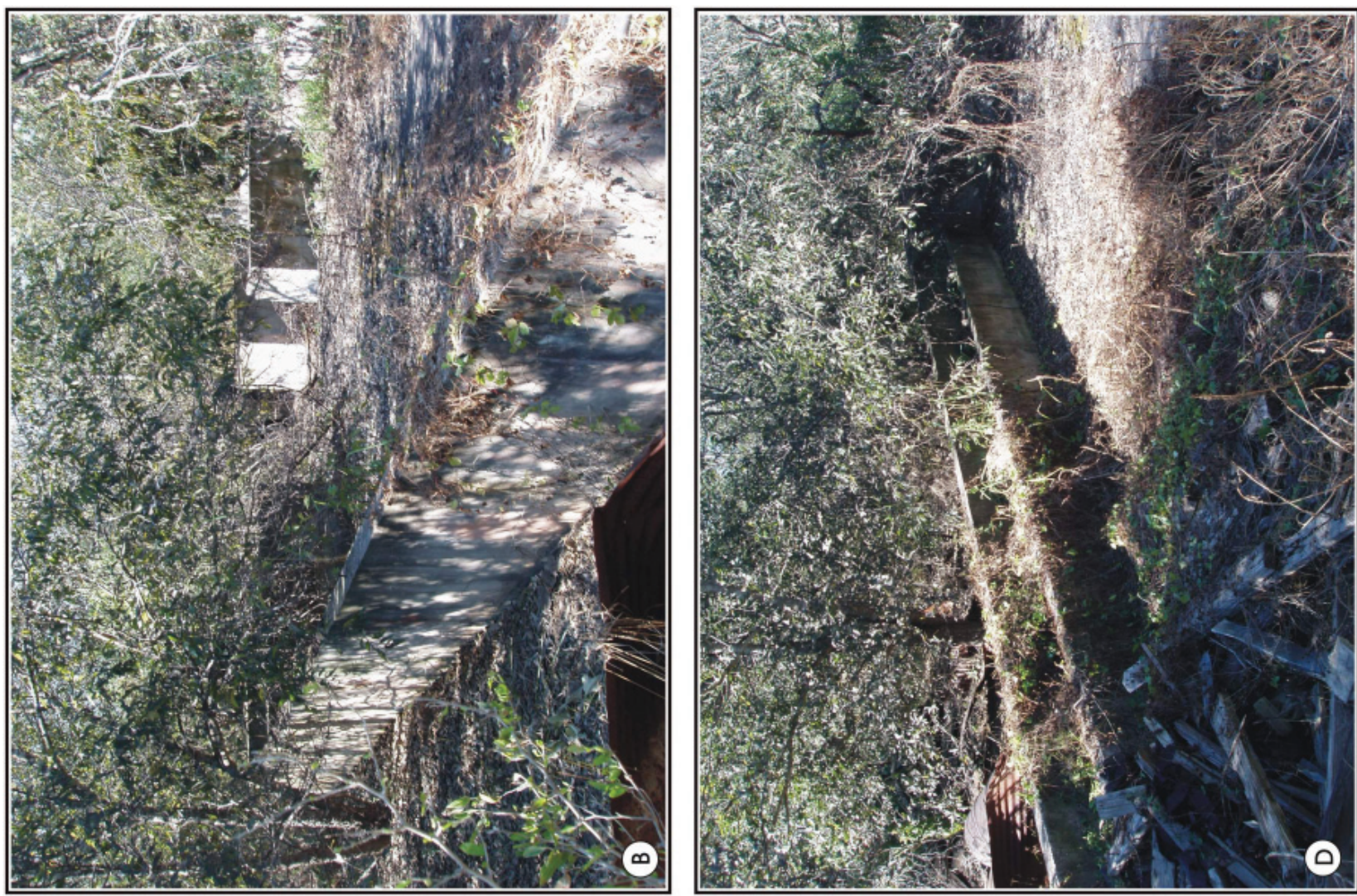

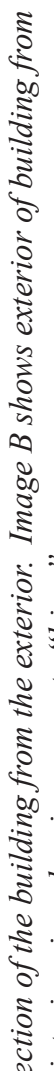
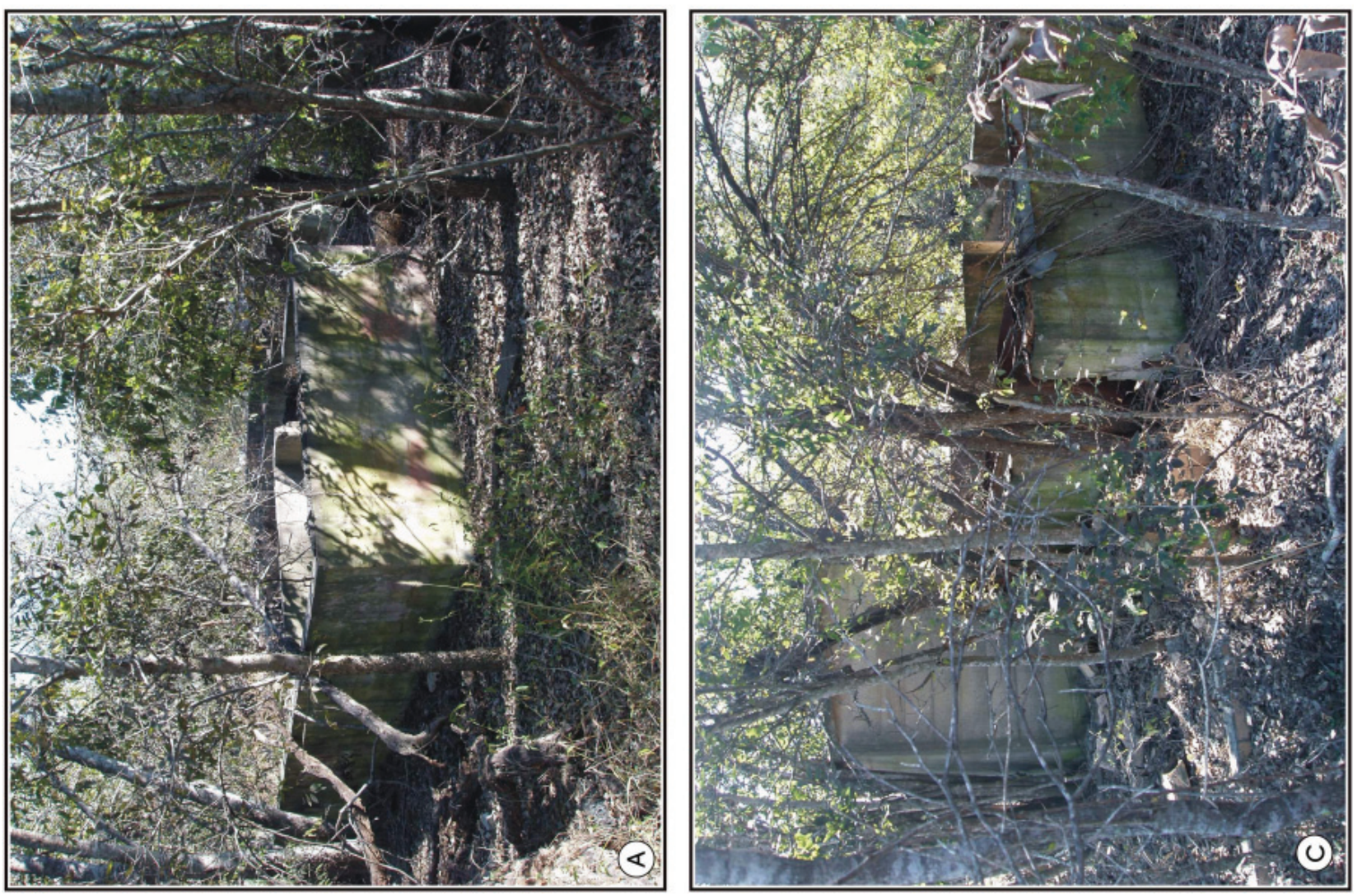

$\pi$

3

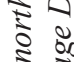

$\stackrel{2}{2} \stackrel{2}{\Sigma}$

-

:

วิ

$\int^{\frac{2}{2}} \frac{\pi}{3}$

$\nabla$ I

$\infty$

ㄴ?

ए

売

:

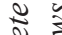

डे

००

苂

คั

मे

0

光 क

理栾 

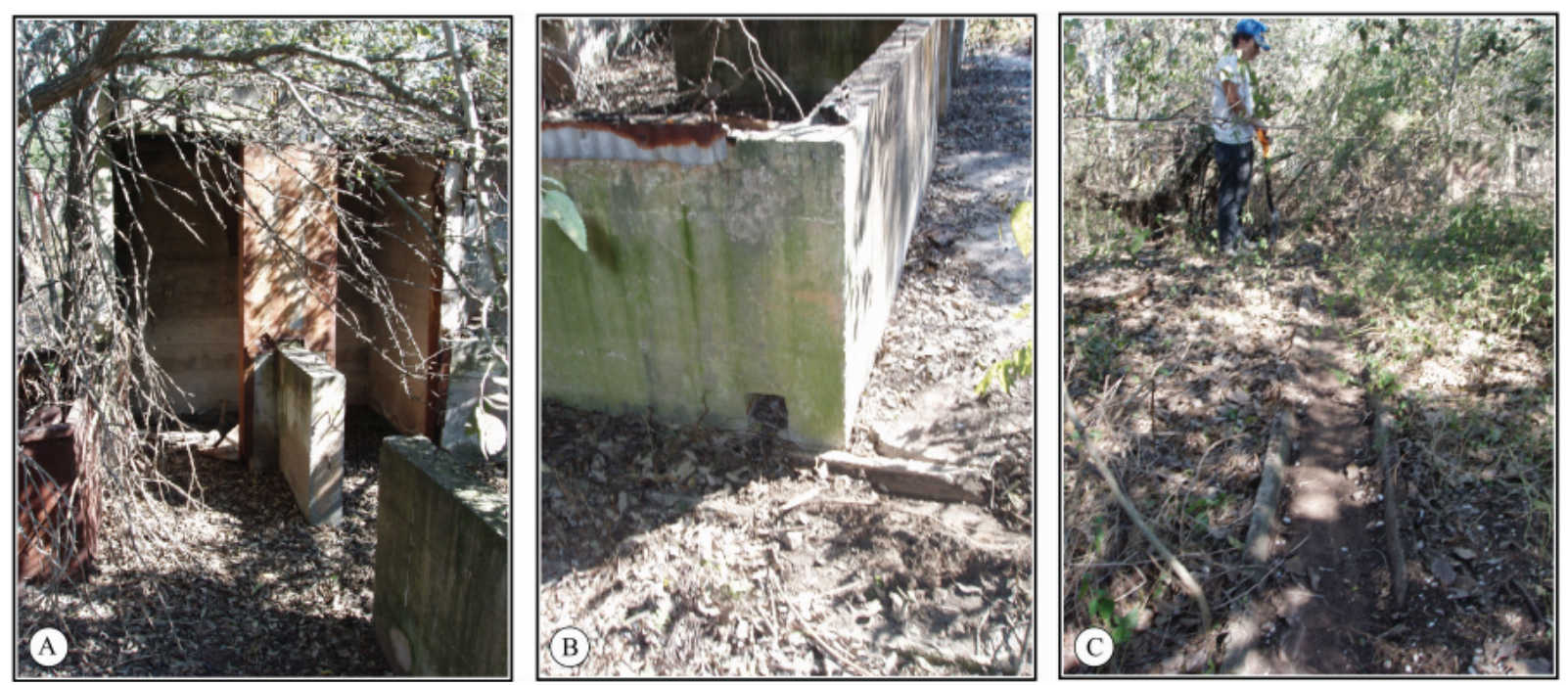

Figure 4-5. Details of concrete structure. Image A shows detail of rooms 3, 4, and 5 from the interior. Image B shows drainage hole from building. Image $C$ shows drainage trough from building.
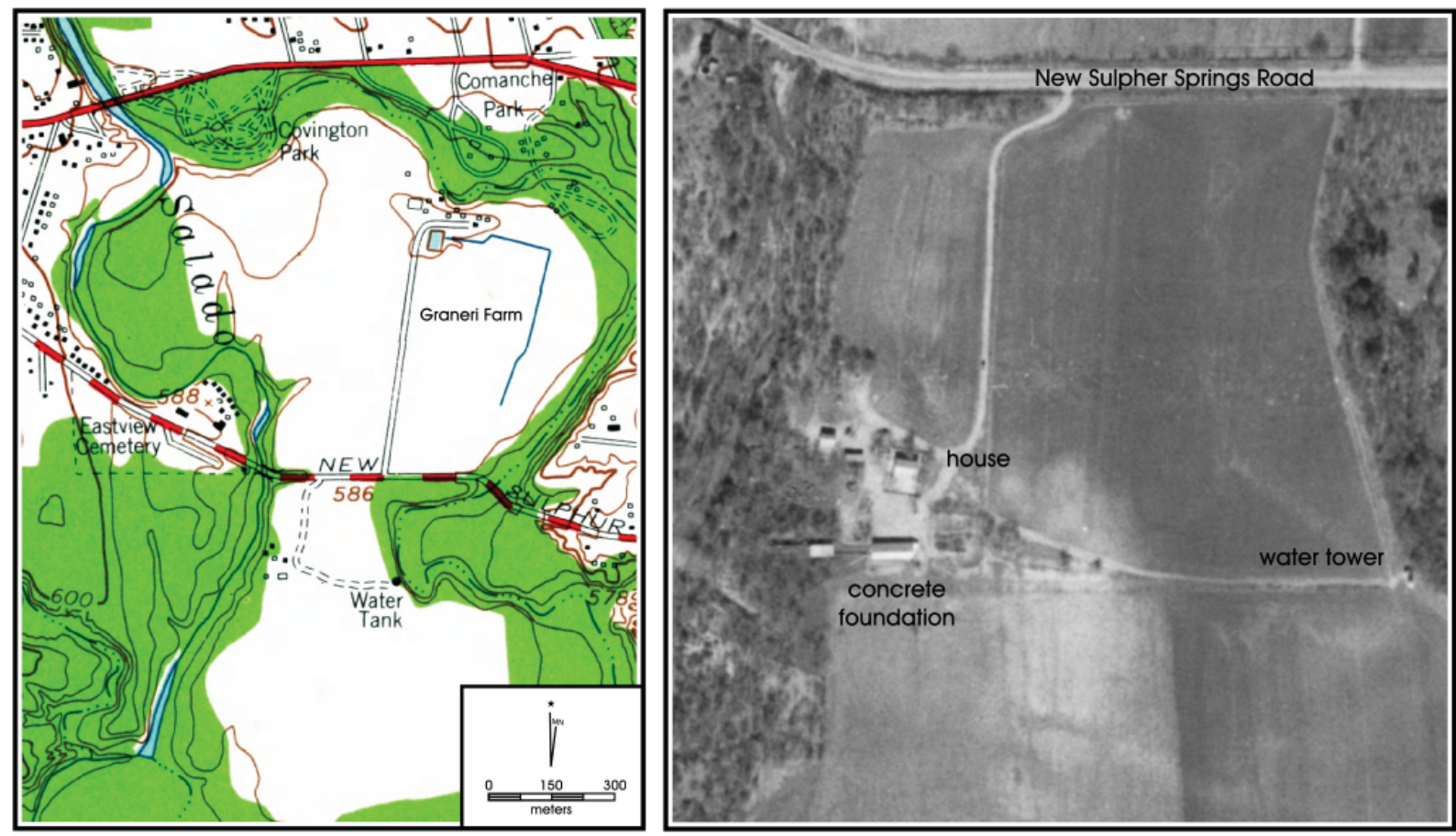

Figure 4-6. The 1953 San Antonio East 7.5 Minute Series U.S.G.S. Quadrangle map and 1937 Tobin aerial photograph of $41 B X 1756$.

(Weston et al. 2004b), CAR excavated five backhoe trenches immediately north of the project area along the Salado Creek. In that investigation, it was determined that alluvial deposits to a depth of 1.5 to $2 \mathrm{~m}$ below the surface were the result of recent flooding (Weston et al. 2004b). Therefore, the Project Archaeologist determined based upon results from shovel tests and the locations of the crossings, with reference to the previous archaeological investigation (Weston et al. 2004b,) that backhoe trenching was not warranted.

\section{Review of Historic Maps}

Archival research conducted in conjunction with the project suggested that historic roads crossed the project area. Based upon this archival research, it was determined that field reconnaissance was necessary to investigate potential historic road crossings through the APE. The following section reviews that investigation and is divided into two parts. The first part details the archival research that justified 
the subsequent field investigation. The second part reports on the findings of the historic road reconnaissance that occurred on 5 November, 2007.

\section{Archival Research}

The data collection phase began with a review of historic maps showing roads entering and leaving San Antonio toward the east and southeast. For the purposes of this study, only roads leading in those directions were considered.

The earliest map available to us at the time of this study was an undated map thought to have been drawn between 1828 and 1838. The map shows a road leaving San Antonio toward the east and crossing Salado Creek within the Courbiere Tract, later known as the Nuñez Tract (Weston et al. 2004b). This route, approximately 3.5 kilometers north of the current project area, appears to predate the Anglo settlements of East Texas and instead served as a route through the Rancho de Molino property owned by Andres Benito Courbiere, the Sergeant at Béxar (Chabot 1937, Weston et al. 2004b). A second road sketched on the map departs San Antonio toward the southeast and forks into two paths, each of which crosses the Salado below the confluence with Rosillo Creek. The two routes merge west of Calaveras Creek and continue on toward the southeast paralleling the San Antonio River. No roads are shown in this early map to cross the Salado in the vicinity of the properties currently under investigation.

Territorial maps drawn in the late pre-Republic period are the first to depict both the Gonzales and the Goliad Roads. Unfortunately, maps of this period are often drawn at a regional scale and thus lack specific details that would help precisely relocate the routes. A number of Bexar County maps produced in the later half of the nineteenth century, including maps by F. H. Arlitt (1868) and W. C. Walsh (1879), also show the Gonzales and Goliad Roads but both contain errors in the curvature of Salado Creek. The mistake, apparently passed on from map to map, fails to show the fork in the Dry and Main Salado channels as well as the large eastern sweeping bend of the Main Salado Creek channel. This mistake seems to have also contributed to the erroneous placement of the Gonzales Road crossing on both maps. Both Arlitt and Walsh place the crossing near the central portion of the Ignacio Perez grant, well north of its likely location. A third Bexar County map drawn in 1887 by J. D. Rullmann also incorrectly illustrates the bends of the Salado, but Rullmann correctly shifts the Gonzales Road to the southern edge of the Perez Tract and also adds the route of the New Goliad Road established in 1854.

A historic surveyor's map drawn by W. H. Owen in 1876 was drafted specifically to record the route of the New Goliad
Road from downtown San Antonio to the Wilson County line (Figure 4-7a). The map, which shows the New Goliad Road to be equivalent to modern Roland Avenue within the project area, also recorded other landmarks including roads, trails, ranchos, waterholes, ruins, homesteads and cemeteries. Within the current project area, four road features from the Owen map were identified as having potential historic significance. The Owen (1876) survey map was than overlaid onto a 2005 aerial photograph. The aerial image aided in the identification of the road traces onto the modern landscape. Beginning in the north (Figure 4-7b), these roads included: the Old Gonzales Road (identified by Areas 1 and 2); a private road segment northwest of the Roland Avenue Bridge over the Main Salado Creek channel (identified by Area 3); the New Goliad Road as established in 1854 (equivalent to modern Roland Avenue); and the "presently traveled route" of the northern Goliad Road segment (identified by Areas 4 through 7). Next, the seven areas of interest were visited to search for physical traces of the roads.

\section{Reconnaissance for the Physical Traces of Historic Roads}

\section{The Old Gonzales Road}

According to Owen's 1876 map, moving from west to east, the Gonzales Road first approaches and crosses the Dry Salado (listed as barranca or canyon on the Owen map) just south of the fork of the two branches of Salado Creek. The road then continues along the south bank of the creek a little more than 120 meters and crosses the stream into what is now Covington Park. The route then cuts diagonally through the playground area of the park and crosses modern Rigsby Avenue and continues out of the project area.

A limited reconnaissance was made in the vicinity of westernmost crossing of the Dry Salado (Figure 4-7b, Area 1). The direction of approach from the west lies within the current floodplain and has been modified by episodic erosion and deposition events. Although privately owned properties west of the Salado were not accessed, the presence of a steep bluff northwest of the fork contrasts to a much gentler rise toward the southwest and suggests that the road made a more southerly bend immediately west of the Salado. The hill and bluff to the northwest of the crossing are the likely location of the Mexican troops described by Austin in his report of October 20,1835; “...enemies out posts are in sight on the top of the hill between this and Bejar." (Austin 1907)

The location of the ford near the fork of the Dry and Main Salado channels is still present. Owen's map (1876) shows the crossing of the Dry Salado to be just below the fork with the main channel. This ford is possible in only one location, 

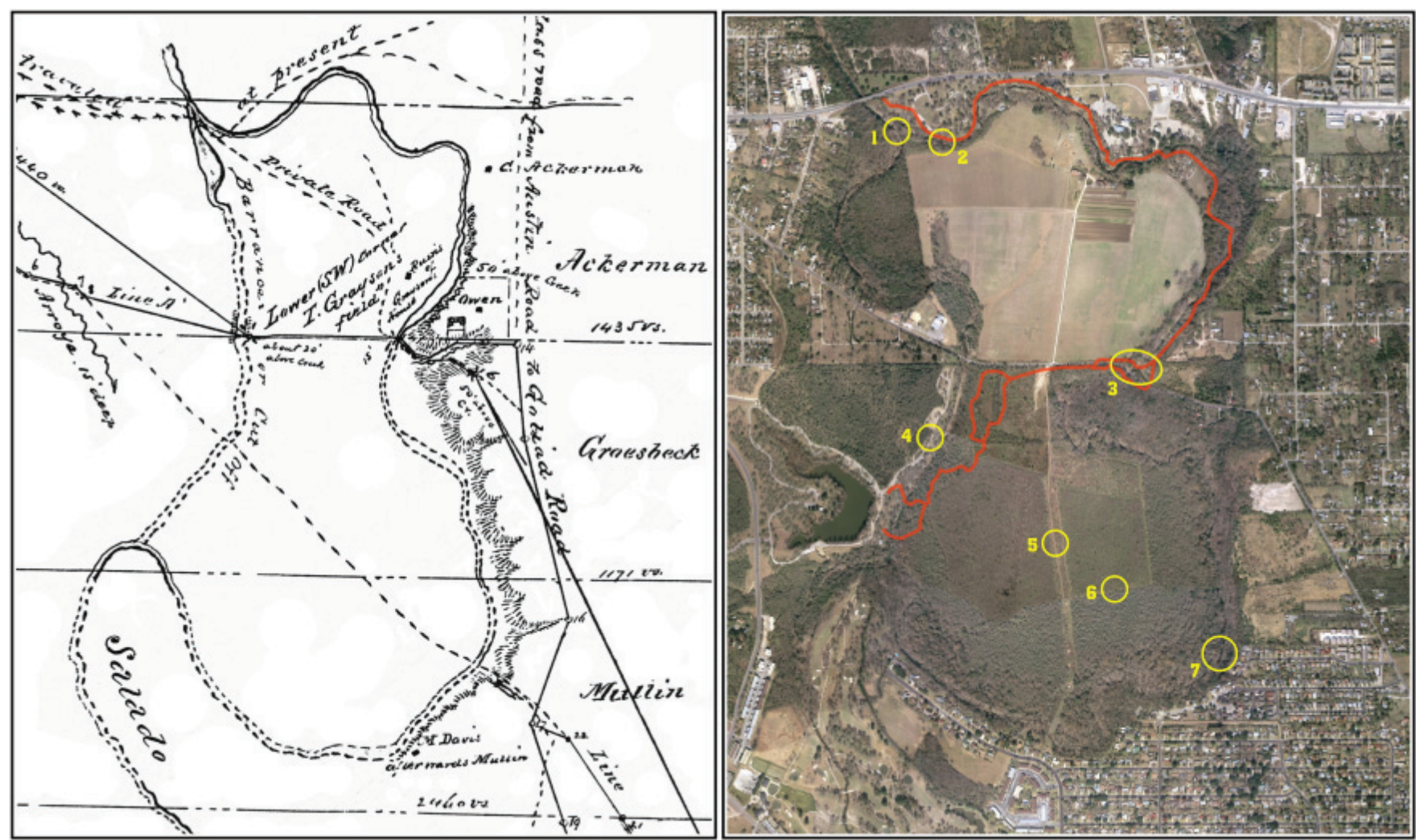

Figure 4-7. Close-up of the 1876 Owen map (left) showing details of roads and rioad traces within the project area. Modern aerial photograph (2005) on the right with locations checked for traces of historic roads.

immediately south of the fork (Figure 4-8). A high terrace rises on the east bank to the south of this area forming a substantial barrier in that direction. North of the crossing and fork, the Salado is wide and the modern channel appears relatively deep.

The ford of the "Dry Salado Creek" leads across to a low and relatively narrow terrace that skirts along the southern bank of the main channel and extends some 120 meters toward the east. South of this feature and also paralleling the stream is a second higher terrace that extends an additional 3 or 4 meters above the first terrace. Taken as a whole, Owen's sketch and the natural lay of the land indicate that the road traversed the lower terrace and crossed into modern Covington Park at a natural ford

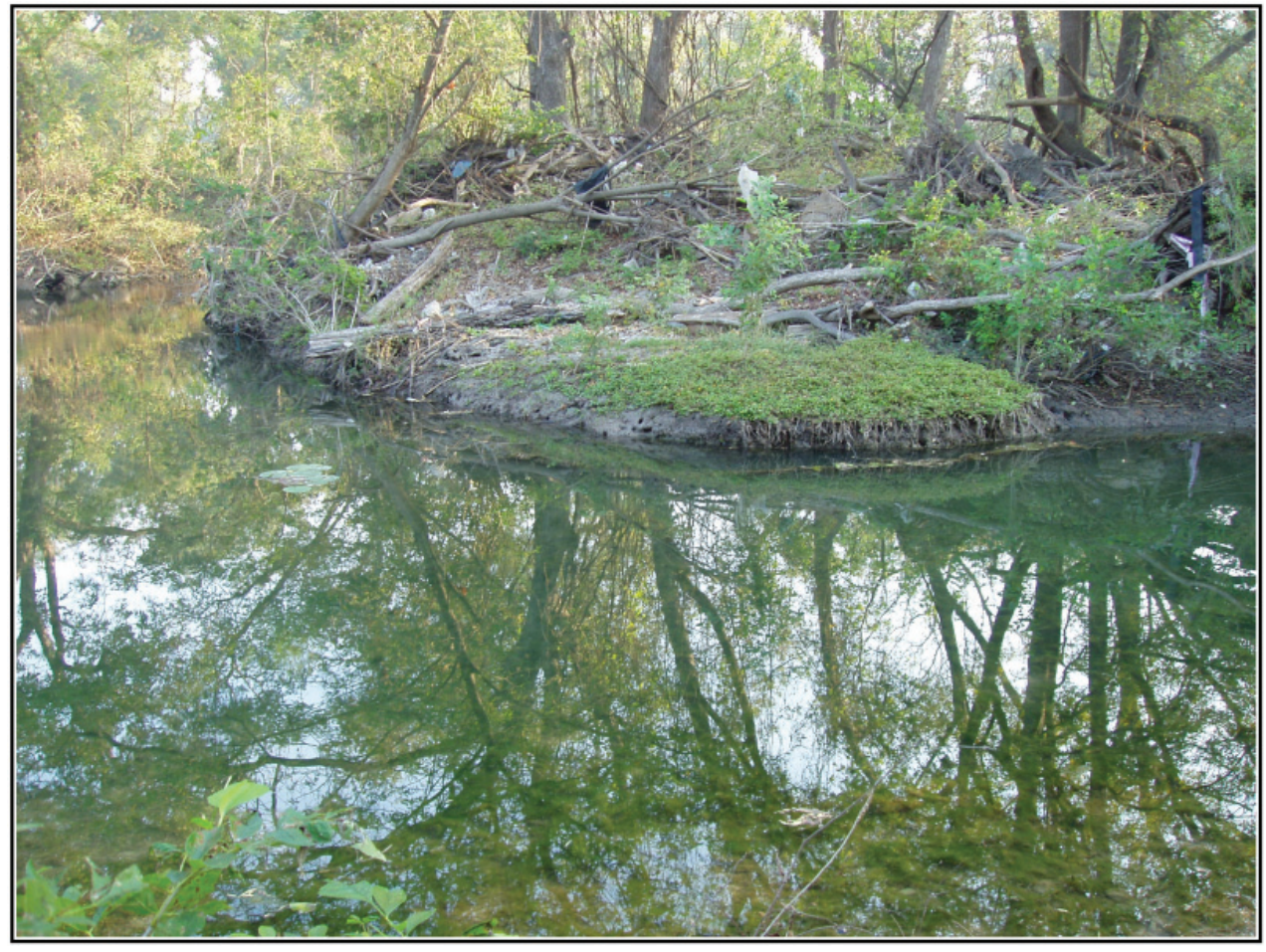

Figure 4-8. Location of the Gonzales Road crossing of the Dry Salado immediately south of the fork in Salado Creek. 
near the terminus of this lower terrace (Figure 4-7, Area 2 and Figure 4-8). The road then crossed into modern Covington Park (Figure 4-9) and continued west in the vicinity of modern Rigsby Avenue.

\section{Private Road Segments near the New Goliad Road}

Several private roads are also sketched on Owen's 1876 map. One trail, currently located on private property, diverges to the northwest from the New Goliad Road (modern Roland Avenue) at the west bank crossing of the Main Salado channel. This road angles abruptly northward approximately 100 meters west of the creek, passing near to the ruins of the Thomas Grayson homestead. Owen's map then shows a portion of the road branch off toward the northwest where it eventually merges with the Gonzales Road just south

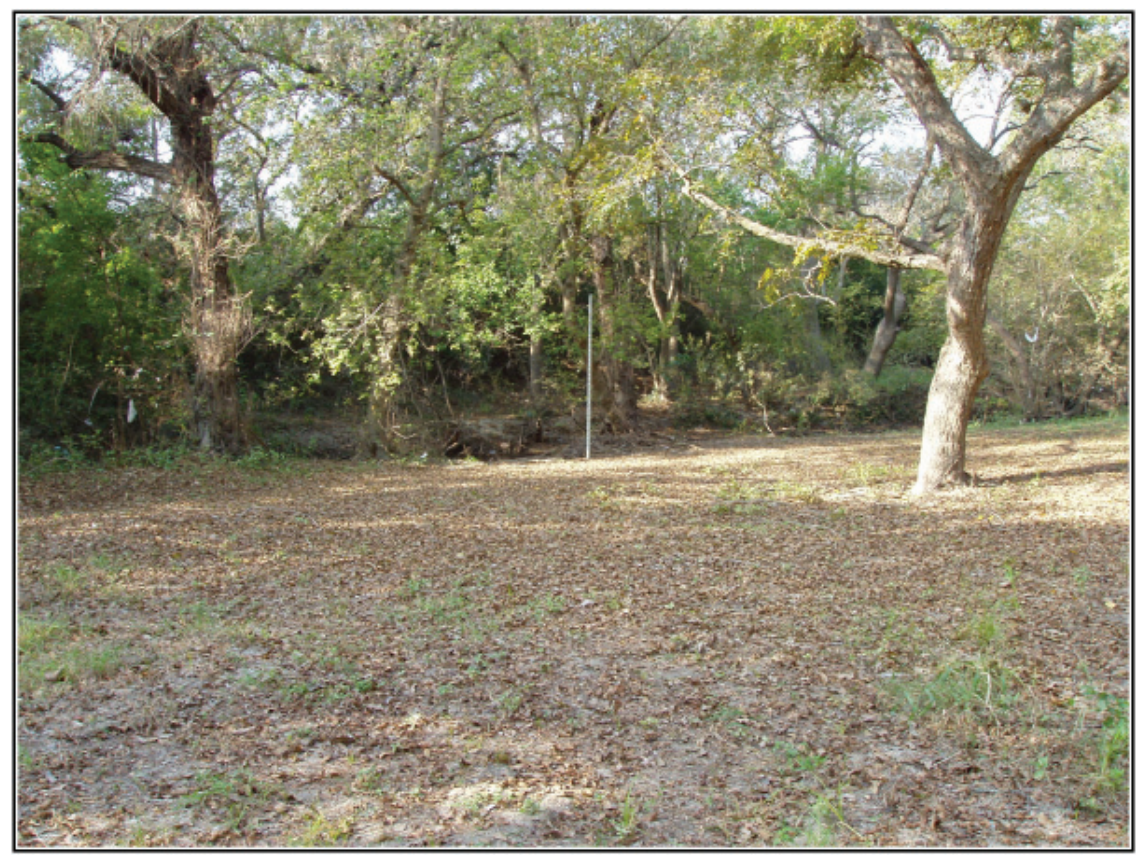
of modern Covington Park.

The area near Roland Avenue was surveyed for traces of this road feature but the results were inconclusive (Figure 4-7, Area 3). It appears that the modern grading of the Roland Avenue ditches approaching Salado Creek have all but erased any surface expressions this route within the current project area. A series of potential low swales located on private property north of Roland Avenue were observed from within the right-of-way of Roland Avenue, but could not be verified. However, a portion of the historic private road does appear as a dark stain on the modern aerial photographs and other changes in vegetation and soil color appear to be present along much of the remainder of the trails route (Figure 4-10). This portion of the private road, the only trace able to be discerned through aerial imagery, is also the only section corresponding to a low relatively open field at the time the aerial was taken.

\section{The New Goliad Road}

Owen's 1876 map was created primarily to survey and record the route of the New Goliad Road established in 1854 and surveyed from San Antonio to the Wilson County line. Within the current project area, this route directly overlays with the modern route of Roland Avenue. All portions of the historic "New Goliad Road" within the modern right-of-way of Roland Avenue likely have been destroyed by grading and road improvements to the route in the ensuing 150 years.

\section{The "Presently Traveled Route" of the North Goliad Road Segment}

This route is delineated on the Owen map by a dotted line crossing into the project area approximately 250 meters south of modern Roland Avenue from the direction of Southside Lion's Park (Figure 4-7b, Area 4). The road, likely representing a route of the Goliad Road utilized between 1848 and 1854 , although possibly dating earlier, angles diagonally toward the southeast and crosses out of the modern Southside Lion's Park East near the intersection of modern Family Tree Drive and Brickhouse Drive. The trail is shown to continue toward the southeast out of the floodplain and pass just north of the modern intersection of East Southcross and South White Road.

Four different areas were checked for traces of this trail (Figure 4-7b, Areas 4-7) across the project area. The first location, marked as Area 4 was estimated based on the location shown on the Owen map. A reconnaissance of both sides of the stream bed in that location failed to turn up any signs of the trail. A more extensive survey was then made along the crest of the east bank terrace beginning at the southernmost portion of the current project area northward to approximately 220 meters south of Roland Avenue. One linear feature matching a possible road trace was investigated within this area. However, the route was located in close proximity to $41 \mathrm{BX} 1757$. 


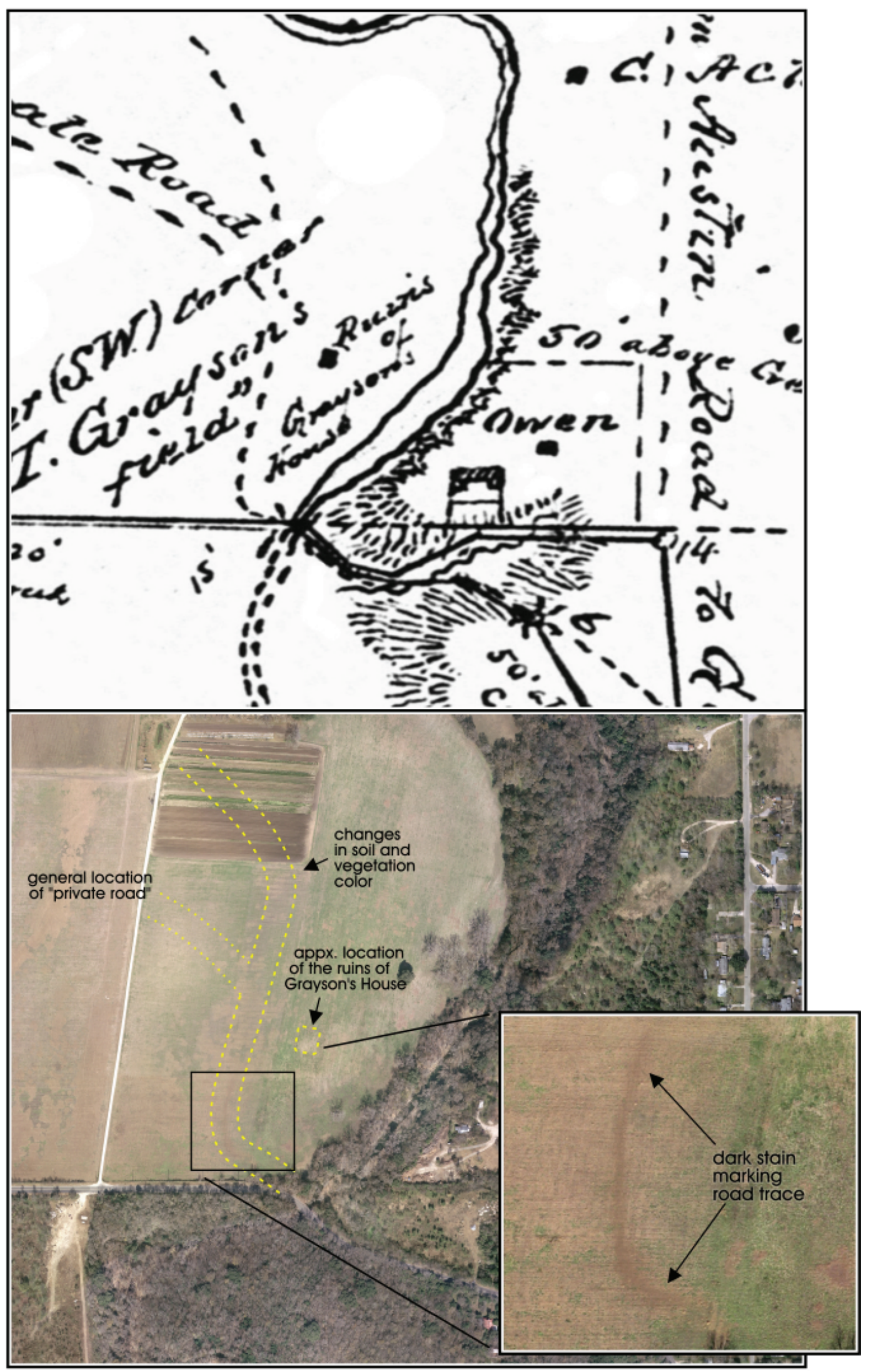

Figure 4-10. Portion of road trace on private property detected using 2005 aerial image. 
In the central portion of Southside Lions Park East, a maintained two-track road running north $\backslash$ south along a grey water septic easement line and a mowed access lane along an eastlwest fence line provided opportunities to search for traces of the road in this portion of the park (Figure 4-7b, Areas 5 and 6). After careful inspection of the grey water septic right-ofway easement, however, it became clear that the area had been impacted severely during the installation of the line. Dense undergrowth across the area made it impossible to survey outside the roadway.

The final area in the vicinity of Salado Creek in the southeastern corner of Southside Lions Park East (Figure 4-7b, Area 7) was also checked for traces of the old road. Based on Owen's map, this area was suspected to be the easiest to relocate traces of the 1876 "presently traveled route" as Owen had detailed a short ravine on the east bank of the river through which the route exited the Salado floodplain. A cursory survey of the west bank of the river was made from the east bank and the presumed location of the old road trace was identified (Figure 4-11). The draw, identified and observed only from a distance because of it's location on private property, appeared to have been largely filled in prior to the development of the subdivision in the area.

An effort to locate this trail on the west side of Salado Creek within the Southside Lions Park East was unsuccessful. The west bank of the creek does not exhibit abrupt changes in terrace elevations in this area but rather offers only a gradual incline rising toward the west.

\section{Summary of the Archaeological Survey}

Fieldwork along the South Salado Creek Greenway project consisted of an intensive pedestrian survey. Forty shovel tests were excavated during the survey with three of these shovel tests positive for cultural materials. Two areas of interest were further investigated with an additional seven shovel tests for a total of forty-seven shovel tests. No deep depositional settings were identified during the fieldwork

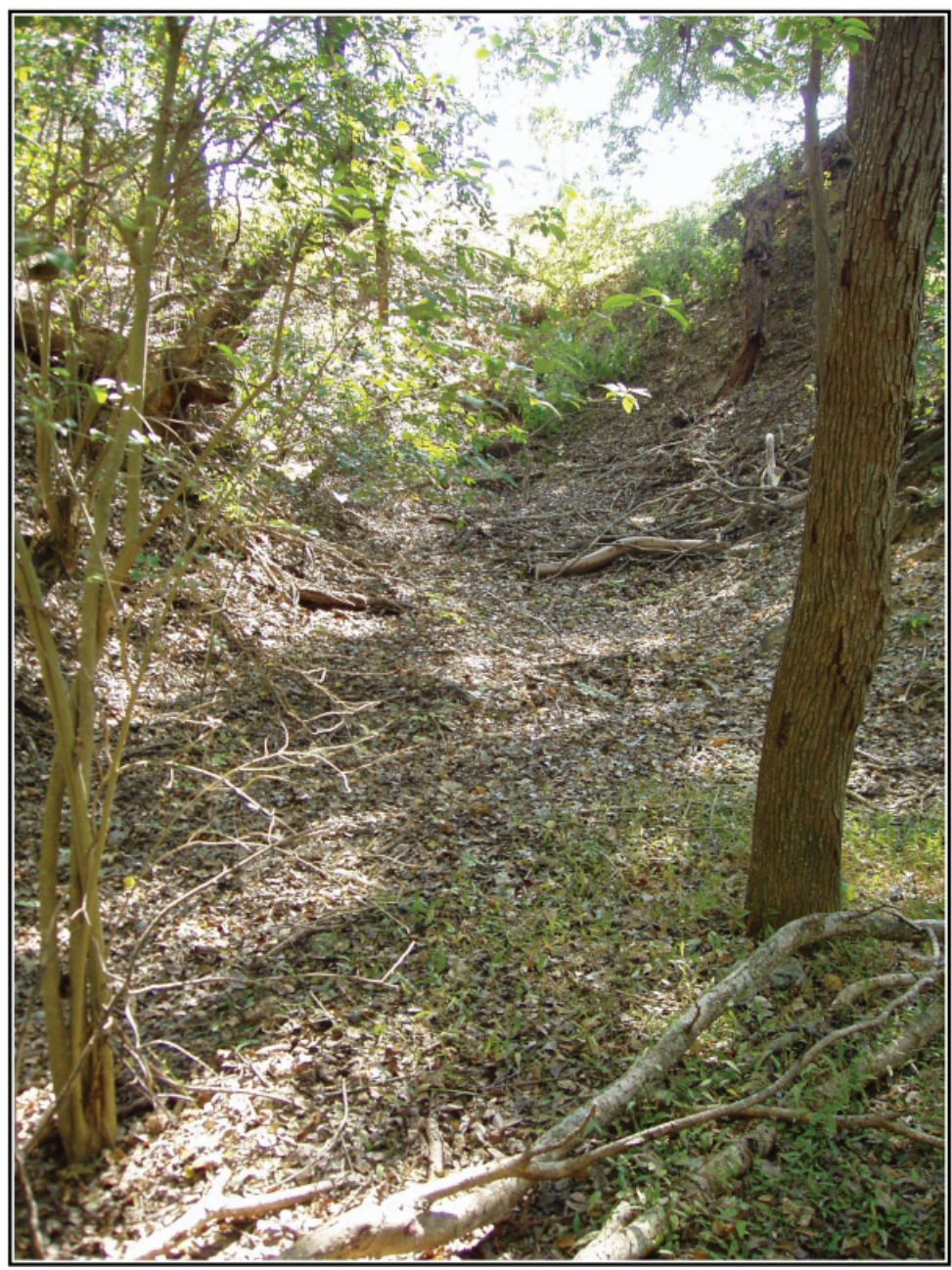

Figure 4-11. Area where the "presently traveled road" depicted on Owen's map exits the Salado Creek floodplain on Area 7.

that necessitated backhoe trenching. One multi-component archaeological site, 41BX1756, was identified during the survey. Archival research suggests that the historical component was a homestead built between 1903 and 1937. In addition, a subsurface prehistoric component consisting of debitage and burned rock was discovered. Field, laboratory, and archival research suggest that neither component has significant research value. Archival and field investigations revealed traces of historic roads that crossed the project area. Note that while these locations cross the project area, they will not be impacted by construction. 


\section{Chapter 5: Summary and Recommendations}

\begin{abstract}
Summary
The Center for Archaeological Research (CAR) of the University of Texas at San Antonio conducted an intensive pedestrian archaeological survey of the South Salado Creek Greenway project area (APE) located in Bexar County, Texas for Rehler, Vaughn \& Koone, Inc. of San Antonio. The survey was conducted under the requirements of the City of San Antonio Unified Development Code Chapter 35, Section 106 of the National Historic Preservation Act (NHPA) of 1966, and the Texas Antiquities Code. The survey was performed under Texas Antiquities Permit No. 4702.
\end{abstract}

The project area is within the Salado Creek watershed in southeast San Antonio bordered by Rigsby Avenue to the north and continuing south into Southside Lion's Park East. Roland Road bisects the project area from the east to the west. The survey was carried out in October and November, 2007. The archaeological work was conducted to determine whether cultural deposits exist in the immediate vicinity of the hike and bike alignment that may be impacted by the planned project.

Of the forty-seven excavated shovel tests along the alignment, four shovel tests were positive for cultural material. One new site, 41BX1756, was found and documented. It is a multi-component site with a historic component consisting of the remains of homestead dated between 1903 and 1937. The structures suffered extensive fire damage prior to this investigation. In addition, this site has a sparse prehistoric component of burned rock and debitage found in two shovel tests. The location of historic roads was investigated through archival research and fieldwork. Findings from these investigations suggest that traces of these roads are still present at creek crossings. No road traces were discovered along or crossing the proposed alignment.

\section{Recommendations}

The archaeological pedestrian survey of the South Salado Creek Greenway APE was completed in accordance with the Antiquities Code of Texas, according to the scope of work submitted to the Texas Historical Commission. Based on the findings from archival, field, and laboratory investigation, CAR recommends that construction can proceed as planned within the alignment. In the course of the survey, CAR documented one multi-component archaeological site, 41BX1756. Field, laboratory and archival investigation suggests that neither prehistoric nor historic components have significant research value. CAR recommends that neither of the site's components is eligible for nomination to the National Register of Historic Places or formal listing as a State Archaeological Landmark. Because this site falls within the alternative trail designation, we suggest that the primary trail be utilized to avoid any impact to the site. Representatives of the City's Park and Recreation Department have confirmed that the primary trail route will be employed in the site's vicinity. In addition, archival and field investigation revealed the remains of historic roads that crossed the project area. While these locations are on city- owned property, they will not be impacted by the proposed construction. In summary, CAR recommends that the South Salado multi-use greenway trail project located between Rigsby Avenue to Southside Lion's Park East along the Salado Creek proceed as planned. 



\section{References Cited}

Almaráz, F.D., Jr.

1971 Tragic Cavalier: Governor Manuel Salcedo of Texas, 1808-1813. University of Texas Press, Austin, Texas

Arlitt, F.H.

1868 Map of Bexar County. Texas General Land Office, Austin.

Austin, S.F.

1830 Map of Texas. Philadelphia.

1907 General Austin's Order Book for the Campaign of 1835. Southwestern Historical Quarterly Online,http://www.tsha. utexas.edu/publications/journals/shq/online/v011/n1/article_5.html, accessed November 12, 2007.

Bannon, J.F.

1974 The Spanish Borderlands Frontier 1513-1821. University of New Mexico Press, Albuquerque.

Barr, A.

1990 Texans in Revolt: the Battle for San Antonio, 1835. University of Texas Press, Austin.

Bexar County Historical Records

2007 http://www.countyclerk.bexar.landata.com. accessed November 2007.

Campbell, R.B.

2003 Gone to Texas: A History of the Lone Star State. Oxford University Press, New York.

Campbell, T.N.

1979 Ethnohistoric Notes on Indian Groups Associated with Three Spanish Missions at Guerrero, Coahuila. Report, No. 3. Center for Archaeological Research, The University of Texas at San Antonio.

Chabot, F.C.

1937 With the Makers of San Antonio: Genealogies of the Early Latin, Anglo-American, and German Families. Artes Graficas, San Antonio.

Collins, M.B.

1995 Forty Years of Archeology in Central Texas. Bulletin of the Texas Archaeological Society 66:361-400.

de la Peña, J.

1975 With Santa Anna in Texas: a Personal Narrative of the Revolution. Texas A\&M University, College Station.

Diamond, D.D., D.H. Riskind, and S.L. Orzell

1987 A Framework for Plant Community Classification and Conservation in Texas. The Texas Journal of Science 39(3):203221. 
Francell, L.

2007 Roads West. http://www.texasonlinepeople//adixon/lancaster/wagon.htm. accessed November 2007.

Gould, F.W.

1975 The Grasses of Texas. Texas A.\&M. Press, College Station.

Hadley, D., T.H. Naylor and M.K. Schuetz-Miller (editors)

1997 The Presidio and militia on the northern frontier of New Spain, a Documentary History: Volume Two, the Central Corridor and the Texas Corridor 1700-1765. University of Arizona Press, Tucson.

Handbook of Texas Online, s.v.

2007 http://www.tsha.utexas.edu/handbook/online/articles/WW/npwnj.html accessed November 2007.

Hester, T.R.

1978 Early Human Occupations in South Central and Southwestern Texas: Preliminary Papers on the Baker Cave and St. Mary's Hall Sites. Center for Archaeological Research, The University of Texas at San Antonio.

1995 The Prehistory of South Texas. Bulletin of the Texas Archeological Society 66:427-459.

Hogan, W.R.

1975 The Texas Republic: A Social and Economic History. University of Texas Press, Austin, Texas.

Hughes, J.D.

1846 Memoir Descriptive of the March of a Division of the United States Army Under Command of General John E. Wool, from San Antonio in Texas to Saltillo, in Mexico. Washington D.C.

Jackson, J.

1986 Los Mesteños: Spanish Ranching in Texas, 1721-1821. Texas A\&M University Press, College Station.

Jackson, J., ed.

2000 Texas by Terán: The Diary Kept by General Manuel de Mier y Terán on His 1828 Inspection of Texas. University of Texas Press, Austin.

Jackson, R.

1997 Alamo Legacy: Alamo Descendants Remember the Alamo. Eakin Press, Austin.

McGraw, A J. and K. Hindes

1987 Chipped Stone and Adobe: A cultural Resource Assessment of the Proposed Applewhite Reservoir, Bexar County,

Texas. Archaeological Report, No. 163. Center for Archaeological Research, The University of Texas at San Antonio.

Newcomb, W.W., Jr.

1961 The Indians of Texas: From Prehistoric to Modern Times. University of Texas Press, Austin.

Montejano, D.

1987 Anglos and Texans in the Making of Texas 1836- 1986. University of Texas Press, Austin. 
Owen, W.H.

1876 Map of New Goliad Road, Bexar County, Texas. Map on file at CAR.

Pitts, J.B.

1966 Speculation in Headright Land Grants in San Antonio from 1837 to 1842. Unpublished Master's Thesis, Department of History, Trinity University, San Antonio.

Potter, D.R., S.L. Black, and K. Jolly

1995 Archaeology along the Wurzbach Parkway, Module 1: Introduction, Conceptual Framework and Contexts of Archaeological Investigations in Bexar County, South-Central Texas. Studies in Archeology 17, Texas Archeological Research Laboratory, The University of Texas at Austin.

Rullmann, J. D.

1887 Map of Bexar County. Texas General Land Office, Austin.

Swift, R.J., and L. Corning

1988 Three Roads to Chihuahua: the Great Wagon Roads the Opened the Southwest, 1823-1883. Eakin Press, Austin.

Taylor, F.B., R.B. Hailey and D.L. Richard

1991 Soil Survey of Bexar County, Texas. United States Department of Agriculture. Soil Conservation Service. Washington, D.C.

Texas General Land Office

n.d. Map of Bexar: Old Bexar County. Texas General Land Office, Austin.

Tomka, S.A., J. Thompson, B.K. Moses, and A.A. Fox

2004 Celebrating Cultural Diversity along the San Antonio River Basin: A Summary of Prehistoric and Historic Cultural Resources. Unpublished manuscript on file, Center for Archaeological Research, The University of Texas at San Antonio.

Walsh, W.C.

1879 Map of Bexar County. Texas General Land Office, Austin.

Weston, J.D.

2004a The Perez Ranch Project reassessment of Four Archaeological Sites in South-central Bexar County, Texas. Archaeological Report, No. 346. Center for Archaeological Research, The University of Texas at San Antonio.

2004b Archaeological Survey for the Proposed Salado Creek Hike and Bike Trail, City of San Antonio, Bexar County, Texas. Archaeological Report, No. 338. Center for Archaeological Research, The University of Texas at San Antonio.

Winders, R.B.

2004 Sacrificed at the Alamo: Tragedy and Triumph in the Texas Revolution. State House Press, Abilene. 



\section{Appendix}

\section{Republic of Texas Army Headquarters on the Salado, Oct. 20-26, 1835}

On October 2, 1835, a detachment of the Mexican army engaged Anglo settlers in the Mexican Texas town of Gonzales in a skirmish known as the Battle of Gonzales. Although considered a minor military engagement, the event precipitated a break between the American colonists and the Mexican government and is considered the beginning of the Texas Revolution (Hardin 2001). A week and a half later, a small army made up of three hundred volunteers from the Anglo colonies was assembled at Gonzales. On October 13, under the direction of Stephen F. Austin, the Texans departed the town with the objective being the garrisoned town of San Antonio de Béxar. The army moved forward along the Gonzales Road as far as Cibolo Creek, where they encountered a small Mexican scouting party (Barr 1990). The Texans, suspecting an ambush, halted and made camp near the Cibolo Creek. Word soon arrived from scouts several miles ahead that a strong Mexican picket force had taken up a position along route in the vicinity of Salado Creek (Austin 1907).

Over the next several days, the small Texan army received much needed reinforcements. Three additional companies and two pieces of artillery arrived at the Cibolo camp. The army's strength was increased to around 450 men by the time Austin was prepared to continue on toward San Antonio (Barr 1990). Early on the morning of October 20, Austin sent out a small squad of hand picked men to lead an advance scouting operation in the direction of the Salado (McKeehan 2003a). Evidence of a Mexican presence along the Gonzales was abundant and soon a group of Mexican foragers was encountered at the Salado. Creed Taylor, a member of the advanced guard reported:

...we came in sight of the foragers at the river and opened fire. The Mexicans were greatly surprised and after an exchange of shots fled in confusion. We gave hot pursuit for two or three miles, and in the running fight Henry Karnes killed one, and another was captured. The captive had his horse killed under him in the first fire at the Salado, and as his horse fell he sustained severe bruises at the knee and was unable to flee with his comrades. In the melee the Mexicans had left several horses, stampeded during the skirmish and it was while rounding up these animals that the wounded man was discovered (McKeehan 2003a).

The scouts took control of the Salado crossings as Austin moved army forward and established camp on the east bank of the Salado in the vicinity of modern Covington Park (McKeehan 2003b). Jim Bowie had joined the army on the grassy plain between the Cibolo and the Salado and was immediately given a position on the staff. The main body of the army approached the Gonzales Road crossing of Salado Creek on the morning of October 20, with the advancedguard encountering Mexican cavalry at the ford. Shots were exchanged by both sides but the Mexicans retired to a ridge on the west bank of the creek where they maintained a look out post for the remainder of the day (McKeehan 2003b). See Figure A-1

One of Austin's first orders from the new camp was addressed to all volunteers continuing to make their way westward along the Gonzales road:

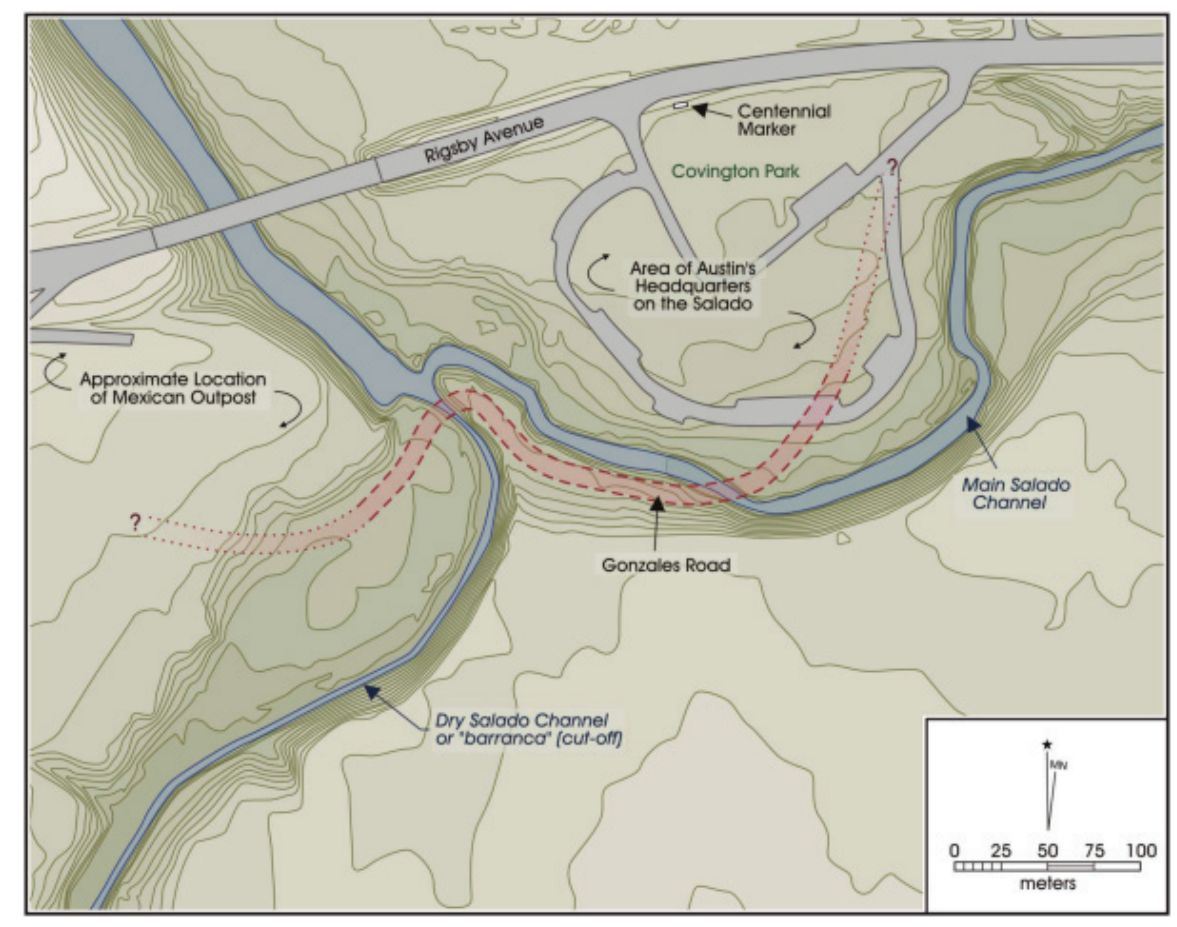

Figure A-1. Location of Austin's camp on South Salado Creek, 1837. 


\section{Head Quarters on the Salado 20th Octr. 1835 To all the Volunteers on the road,}

The army took up this position early this morning. The enemies outposts retired before our spies and advance without loss on either side. This position is within less than five miles of Bejar. The enemies out posts are in sight on the top of the hill between this and Bejar. The reinforcements are specially ordered to push on by forced Marches-on this side of the Civolo they ought to march in companies of not less than ten or fifteen. It is particularly enjoined on all the Volunteers who arrive at Gonzales to furnish a guard for the beeves that Mr. Kent or Mr. Fuqua are bringing on.

\section{S F. Austin Comr in chief By order Warren D C Hall Adjt Genl. (Austin 1907).}

General Cos, learning that the Texan Army was now encamped on the outskirts of town, pulled his troops back and began preparing a strong defensive position inside the town and at the Alamo garrison (Winders 2004). Both the Texans and Mexicans received much needed reinforcements during the week. Approximately 135 Mexican Texans led by Juan Seguín entered the Camp on the Salado on October 22 (de la Teja, 1991). Recruits also arrived at the camp from Goliad and the ranches and farms south of San Antonio. Seguín later recalled riding into the camp on the Salado with his forces and meeting with Austin:
Upon this occasion I had the opportunity to become acquainted with General Sam Houston, who accompanied Austin. On the same day we had a slight engagement with the forces under Cos, who retired into San Antonio. Austin, as Commander-in-Chief of the Army, gave me the appointment of Captain (de la Teja, 1991).

Seguín was then sent out to obtain provisions from other Mexican civilians living in the nearby countryside. Austin took advantage of the time at the Salado Camp by drilling the fledgling Texan Army while waiting for additional volunteers and provisions to arrive. General Cos sent out bodies of cavalry to challenge the Texans daily and skirmishes occurred regularly near the Texan's camp (Winders 2004). Ambrose Rodriguez, a San Antonio resident, kept Austin posted on matters in Béxar (McKeehan 2003a).

On October 22, Austin instructed Colonel Bowie along with Captain James Fannin to take the newly formed First Division of the First Battalion (90 men) to reconnoiter south of Béxar in the vicinity of the missions (Austin 1907). The main Texan army remained encamped on the Salado until the twentyseventh. On October 26, 1835, Bowie and Fannin reported that a small group of Mexican pickets had been encountered at Mission Espada had been driven from the field (Barr 1990). At the suggestion of his two colonels, Austin shifted the Headquarters to Mission Espada, on the San Antonio River, and about ten miles below town. The Texan Army's former campsite on Salado Creek saw no additional noteworthy action during the remainder of the conflict.

\section{References}

Almaráz, F.D., Jr.

1971 Tragic Cavalier: Governor Manuel Salcedo of Texas, 1808-1813. University of Texas Press, Austin.

Austin, S.F.

1907 General Austin's Order Book for the Campaign of 1835. Southwestern Historical Quarterly Online 11(1). Electronic document, http://www.tsha.utexas.edu/publications/journals/shq/online/v011/n1/article 5.html, accessed November $12,2007$.

Barr, A.

1990 Texans in Revolt: the Battle for San Antonio, 1835. University of Texas Press, Austin.

de la Teja, J.F., ed.

1991 A Revolution Remembered: The Memoirs and Selected Correspondence of Juan N. Seguin. State House Press, Austin. 
Hardin, S.L.

2001 Battle of Gonzales. Handbook of Texas Online. Electronic document, http://www.tsha.utexas.edu/handbook/online/ articles/GG/qeg3.html, accessed November 11, 2007.

McKeehan, W.L.

2003a Creed Taylor. The March, the Siege and the Battle for Bexar Oct-Dec 1835. Electronic document, http://www.tamu. edu/ccbn/dewitt/batbexarcreed.htm, accessed November 12, 2007.

2003b William T. Austin's Account Siege \&Battle of Béxar 1844. Muster at Gonzales and Battle of Béxar. Electronic document, http://www.tamu.edu/ccbn/dewitt/bexaraustinwt.htm, accessed November 12, 2007.

Noah S.

1997 The Evolution of a State or Recollections of Old Texas Days. Electronic document, http://www.oldcardboard.com/lsj/ olbooks/smithwic/otd.htm, accessed November 12, 2007.

Winders, R.B.

2004 Sacrificed at the Alamo: Tragedy and Triumph in the Texas Revolution. State House Press, Abilene. 